\begin{tabular}{|l|l|l|l|l|l|}
\hline \multirow{2}{*}{$\sim$} & S E D & 12105 & \multirow{2}{*}{ WILEY } & Dispatch: 29.1.14 & CE: Supriya \\
\cline { 2 - 3 } \cline { 5 - 6 } & Journal Code & Manuscript No. & & No. of pages: 36 & PE: Sudhakar G \\
\hline
\end{tabular}

\title{
Deep incision in an Aptian carbonate succession indicates major sea-level fall in the Cretaceous
}

\author{
TELM BOVER-ARNAL *, RAMON SALAS *, JOAN GUIMERÀ† and JOSEP ANTON \\ MORENO-BEDMAR+ \\ *Departament de Geoquímica, Petrologia i Prospecció Geològica, Facultat de Geologia, Universitat de \\ Barcelona, Martí i Franquès s/n, 08028 Barcelona, Spain (E-mail: telm.boverarnal@ub.edu) \\ $\dagger$ †epartament de Geodinàmica i Geofísica, Facultat de Geologia, Universitat de Barcelona, Martí $i$ \\ Franquès s/n, 08028 Barcelona, Spain \\ ¥Instituto de Geología, Universidad Nacional Autónoma de México, Ciudad Universitaria, Coyoacán, \\ 04510 México D.F., Mexico
}

Associate Editor - Gregor Eberli

\begin{abstract}
Long-term relative sea-level cycles (0.5 to $6 \mathrm{Myr}$ ) have yet to be fully understood for the Cretaceous. During the Aptian, in the northern Maestrat Basin (Eastern Iberian Peninsula), fault-controlled subsidence created depositional space, but eustasy governed changes in depositional trends. Relative sea-level history was reconstructed by sequence stratigraphic analysis. Two forced regressive stages of relative sea-level were recognized within three depositional sequences. The first stage is late Early Aptian age (intra Dufrenoyia furcata Zone) and is characterized by foreshore to upper shoreface sedimentary wedges, which occur detached from a highstand carbonate platform, and were deposited above basin marls. The amplitude of relative sea-level drop was in the order of tens of metres, with a duration of $<1$ Myr. The second stage of relative sea-level fall occurred within the Late Aptian and is recorded by an incised valley that, when restored to its pre-contractional attitude, was $>2 \mathrm{~km}$ wide and cut $\geq 115 \mathrm{~m}$ down into the underlying Aptian succession. With the subsequent transgression, the incision was back-filled with peritidal to shallow subtidal deposits. The changes in depositional trends, lithofacies evolution and geometric relation of the stratigraphic units characterized are similar to those observed in coeval rocks within the Maestrat Basin, as well as in other correlative basins elsewhere. The pace and magnitude of the two relative sea-level drops identified fall within the glacio-eustatic domain. In the Maestrat Basin, terrestrial palynological studies provide evidence that the late Early and Late Aptian climate was cooler than the earliest part of the Early Aptian and the Albian Stage, which were characterized by warmer environmental conditions. The outcrops documented here are significant because they preserve the results of Aptian long-term sea-level trends that are often only recognizable on larger scales (i.e. seismic) such as for the Arabian Plate.
\end{abstract}

Keywords Aptian, carbonate platforms, Iberian plate, incised valley, sea-level changes, sequence stratigraphy.

\section{INTRODUCTION}

Deciphering long-term relative sea-level fluctuations $(0.5$ to $6 \mathrm{Myr})$ in Aptian sedimentary successions has palaeoclimatic relevance given that some of the amplitudes and frequencies of relative sea-level change reported for this stage are attributed to glacio-eustatic controls (e.g. 
Hillgärtner et al., 2003; Gréselle \& Pittet, 2005; Bover-Arnal et al., 2009; van Buchem et al., 2010; Maurer et al., 2010, 2013; Husinec et al., 2012). Glacio-eustasy in the Aptian is controversial because of the classic, widespread idea of stable greenhouse conditions during the Cretaceous (e.g. Wilson \& Norris, 2001; Skelton, 2003a; Hay, 2008, 2011). However, palynological data and oxygen-isotope analyses from Aptian strata and fossil biogenic components have revealed the existence of cold episodes (Krassilov, 1973; Weissert \& Lini, 1991; Ditchfield et al., 1994; Solé de Porta \& Salas, 1994; Stoll \& Schrag, 1996; Abreu et al., 1998; Clarke \& Jenkyns, 1999; Ferguson et al., 1999; Hochuli et al., 1999; Pucéat et al., 2003; Steuber et al., 2005; Amiot et al., 2011; Cors et al., 2013), which may have increased ice volume on the continents and subsequently lowered global sea-level. Further evidence supporting climate cooling events in the Aptian include ice-rafted debris and glendonites in high latitudes (Pickton, 1981; Kemper, 1987; Frakes \& Francis, 1988, 1990; De Lurio \& Frakes, 1999; Price, 1999; Alley \& Frakes, 2003); palaeomigrational patterns of high-latitude calcareous nannofossils towards lower latitudinal sites (Herrle \& Mutterlose, 2003; Rückheim et al., 2006; Mutterlose et al., 2009) and finally, some of the Aptian relative sea-level drops documented seem to be coeval (Hardenbol et al., 1998; Gréselle \& Pittet, 2005; Bover-Arnal et al., 2009, 2010; van Buchem et al., 2010; Maurer et al., 2010, 2013; Husinec et al., 2012; Rameil et al., 2012), despite the limitations of chronostratigraphic frameworks mostly based on ammonite, rudist, planktonic foraminiferal and orbitolinid biostratigraphy.

When reconstructing the relative sea-level history of a sedimentary succession, the recognition of emersion surfaces is of key importance since these are commonly taken as the basis of the chronological framework. In the sequence stratigraphic models of Vail et al. (1977), Posamentier et al. (1988), van Wagoner et al. (1988) and Hunt \& Tucker (1992), subaerial unconformities, and their marine correlative conformities, are regarded as primary sequence boundaries. In these four models, exposure surfaces are associated with stratigraphic hiatuses resulting from non-deposition and erosion during base-level fall.

In ancient subaerially exposed carbonate systems, sedimentological or diagenetic evidence of emersion is at times absent, or can be very subtle or ambiguous (e.g. Hillgärtner, 1998; Immenhauser et al., 1999; Raven et al., 2010; Rameil et al., 2012). The preservation of a subaerially exposed surface depends on the duration of the exposure time, the magnitude of the relative sealevel fall, the resistance of the rocks exposed to physical and chemical alteration, and the intensity in which the atmospheric agents, biological activity, hydrological processes and pedogenesis act. Furthermore, with subsequent marine onlap, evidences of subaerial exposure are often concealed or removed by marine ravinement and by the activity of organisms. On the other hand, however, seismic-scale incisions down-cutting carbonate platforms, with a peritidal back-fill, constitute an unequivocal sign of relative sealevel fall and subaerial exposure of the platform (e.g. Bover-Arnal et al., 2009, 2010, 2011a; Raven et al., 2010; Maurer et al., 2013).

Stratigraphic analysis of the Aptian sedimentary record of the northern Maestrat Basin (Iberian Chain; E Iberian Peninsula) permits the recognition of three differentiated stages of carbonate platform development, terminated by drowning or subaerial exposure. Associated with a Late Aptian emersion phase, a conspicuous seismic-scale incision down-cuts the Aptian succession by $115 \mathrm{~m}$. This incision, which is filled with peritidal to shallow subtidal deposits, provides conclusive evidence of the amplitude of the long-term relative sea-level changes controlling accommodation during the Aptian in the northern part of the Maestrat Basin, and thus deserves special consideration.

The aims of this study were to (i) reconstruct the Aptian long-term relative sea-level history of the northern Maestrat Basin; (ii) measure the amplitude and duration of the relative sea-level falls recognized in order to test glacio-eustasy as a potential controlling mechanism; (iii) generate a two-dimensional (2D) profile of the seismicscale incision affecting the Aptian succession to measure its dimensions and to understand its shape; (iv) analyse the stratal architecture and lithofacies evolution of the carbonate systems to attain a depositional model for these platform carbonates and (v) compare and contrast the results with other Aptian sedimentary systems, distinguishing regional and potential global patterns. Ultimately, this research documents an important piece of the Aptian relative sea-level history and carbonate platform development from the northern margin of the Tethys. The results are of potential interest for future refinements to the Aptian eustatic sea-level curves. 


\section{GEOLOGICAL SETTING}

The Maestrat Basin developed as a result of Late Jurassic (Late Oxfordian)-Early Cretaceous (Middle Albian) continental rifting that affected the Iberian plate (Salas \& Casas, 1993; Salas et al., 2001). Rifting was related to the spreading of the Central Atlantic domain and opening of the Bay of Biscay. During extension, the Maestrat Basin was compartmentalized into seven sub-basins, where kilometre-thick successions of mixed carbonate-siliciclastic deposits accumulated in continental to hemipelagic depositional environments (Canérot et al., 1982; Salas, 1987). As a consequence of the Alpine contraction during the Late Eocene-Early Miocene, the Maestrat Basin was tectonically inverted, which gave rise to the eastern part of the Iberian Chain (Fig. 1; Guimerà, 1984; Salas \& Casas, 1993; Salas et al., 2001).

The Aptian strata studied in the northern Maestrat Basin are divided into three formations: Forcall, Villarroya de los Pinares and Benassal (Canérot et al., 1982; Salas, 1987; Salas et al., 2001; Fig. 2). This succession was deposited in tropical to subtropical neritic marine settings, and is characterized by limestone and marl lithologies, which contain orbitolinid benthic foraminifera, rudist bivalves, corals and ammonites. The Forcall and Villarroya de los Pinares formations are Early Aptian in age (Canérot et al., 1982; Salas, 1987; Salas et al., 2001; Bover-Arnal et al., 2010, 2011b; MorenoBedmar et al., 2010), while the Benassal Formation spans the latest Early Aptian-Late Aptian interval (Bover-Arnal et al., 2012; Moreno-Bedmar et al., 2012a; Garcia et al., 12014 ); Fig. 2.

In the study area, the Aptian record is capped by a regional erosional unconformity overlain by Miocene conglomerates (Fig. 1C). For a detailed geological background of the Maestrat Basin and its sub-basins, refer to Canérot et al. (1982), Salas (1987), Salas \& Casas (1993), Salas \& Guimerà (1996) and Salas et al. (2001).

In the Morella Sub-basin (northern Maestrat Basin; Salas \& Guimerà, 1996; Fig. 1B), the Forcall, Villarroya de los Pinares and Benassal formations crop out along five hillocks (the so-called 'Moles'): Mola de Morella, Mola de la Vila, Mola d'en Camaràs, Mola de la Garumba and Mola de la Saranyana (Fig. 1C). The outcrops are located in the surroundings of the Morella, el Forcall, la Todolella and Xiva de Morella villages (Comarca of Els Ports).

\section{MATERIALS AND METHODS}

A geological map of the Mola d'en Camaràs (Fig. 1) was made to produce a 2D geological cross-section of the seismic-scale incision that down-cuts Aptian strata. The map was created, in a georeferenced frame, over a colour orthoimage at scale $1: 5000(0.5 \mathrm{~m}$ per pixel) by the Spanish Centro Nacional de Información Geográfica (sheet 545; available at http://www. cnig.es). Elevations were procured from the $1: 25000$ topographic map (sheet 545; $10 \mathrm{~m}$ contour line interval, also available at http:// www.cnig.es). Line drawing and mapping of lithofacies architecture and key stratigraphic surfaces were performed on panoramic photomosaics of the steep cliffs delimiting the five hillocks studied. The different lithofacies identified were sampled to produce thin sections $(n=65)$ for the analysis of the microfacies. The terminology used for rock textures follows the classification schemes of Dunham (1962) and Embry \& Klovan (1971).

Sequence stratigraphic interpretation is based on the 'four-system-tract' model of Hunt \& Tucker (1992), but follows the proposed standard sequence stratigraphic nomenclature by Catuneanu et al. (2009). The duration of longterm cyclic variations in depositional trends characterized is consistent with the third-order relative sea-level cycles of Vail et al. (1991). Biostratigraphic analysis of ammonites (MorenoBedmar et al., 2009, 2010, 2012a; Garcia et al., 2014), rudists (Skelton, 2003b; Skelton \& Gili, 2012) and orbitolinids (Schroeder et al., 2010; Cherchi \& Schroeder, 2012) was used to calibrate the relative age of the strata studied.

\section{LITHOF ACIES CLASSIFICATION}

The different lithofacies identified in the field and in thin sections are grouped into five major facies associations, which represent distinct depositional environments and correspond to seismic-scale building blocks of the overall stratal architecture (Fig. 3). Classification is based on the recognition of clinoform surfaces and facies heterogeneity along platform to slope to basin depositional profiles. This large-scale lithofacies evolution pattern repeats throughout the Aptian record studied; only interrupted by the occurrence of platform-detached high-energy wedges and the sedimentary deposits that back-fill the incision down-cutting platform carbonates 

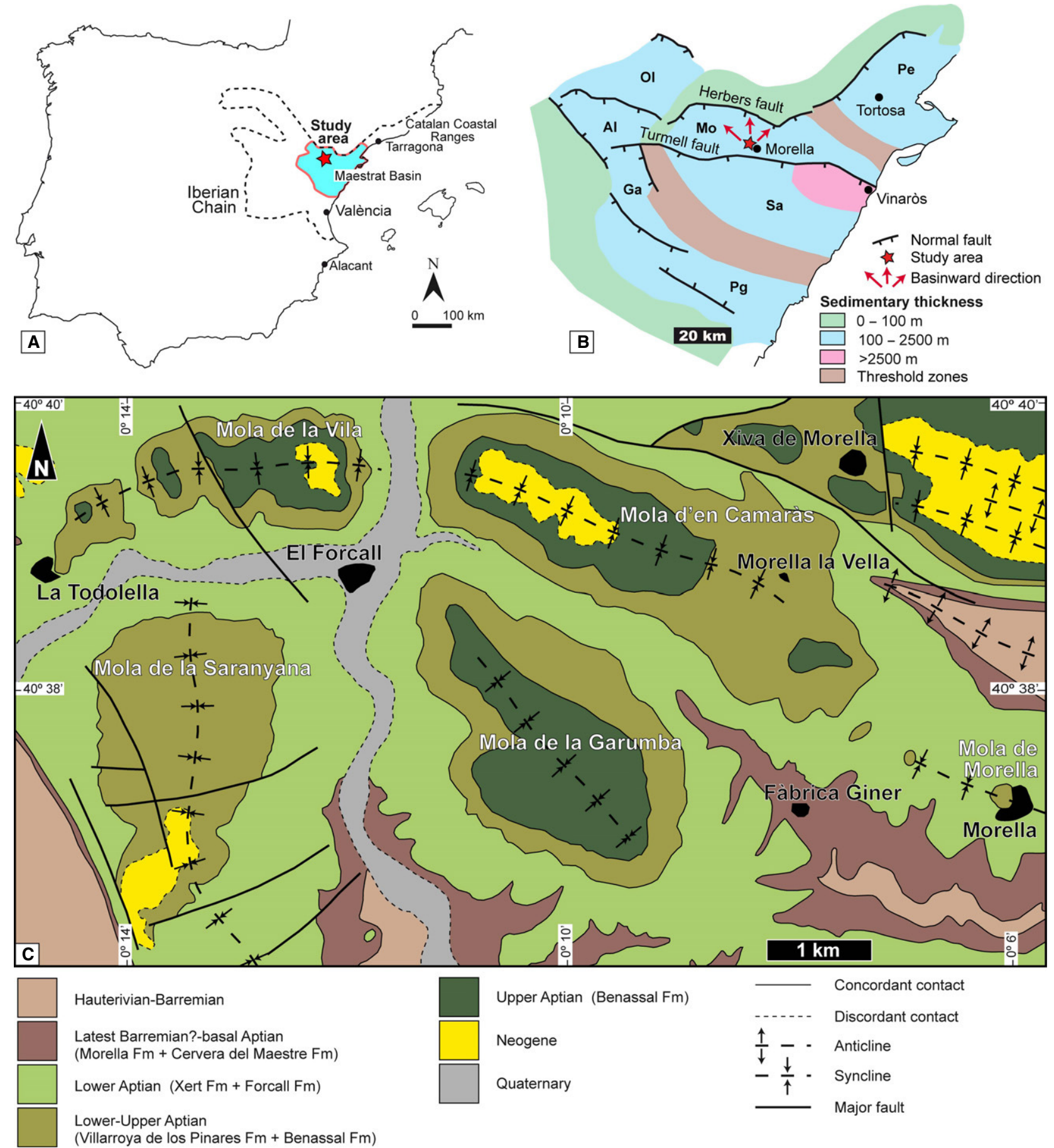

Fig. 1. (A) Geographical setting of the study area in the eastern Iberian Chain (East Iberian Peninsula). (B) Simplified palaeogeographic and structural map of the Maestrat Basin during the Late Jurassic-Early Cretaceous rifting cycle and location of the study area in the Morella Sub-basin. Mo, Morella Sub-basin; Pe, El Perelló Sub-basin; Sa, La Salzedella Sub-basin; Ga, Galve Sub-basin; Ol, Oliete Sub-basin; Al, Aliaga Sub-basin; Pg, Penyagolosa Sub-basin. Modified after Salas et al. (2001). (C) Geological setting of the studied hillocks. Modified after NavarroVázquez et al. (1972) and Martín et al. (1972).

(Fig. 3). The geographical positions of the outcrop views, facies details and microfacies shown in this paper are indicated in Fig. 4.

\section{Platform lithofacies association}

The main lithofacies generated in platform-top settings are decimetre-thick to tens of metres-thick, 


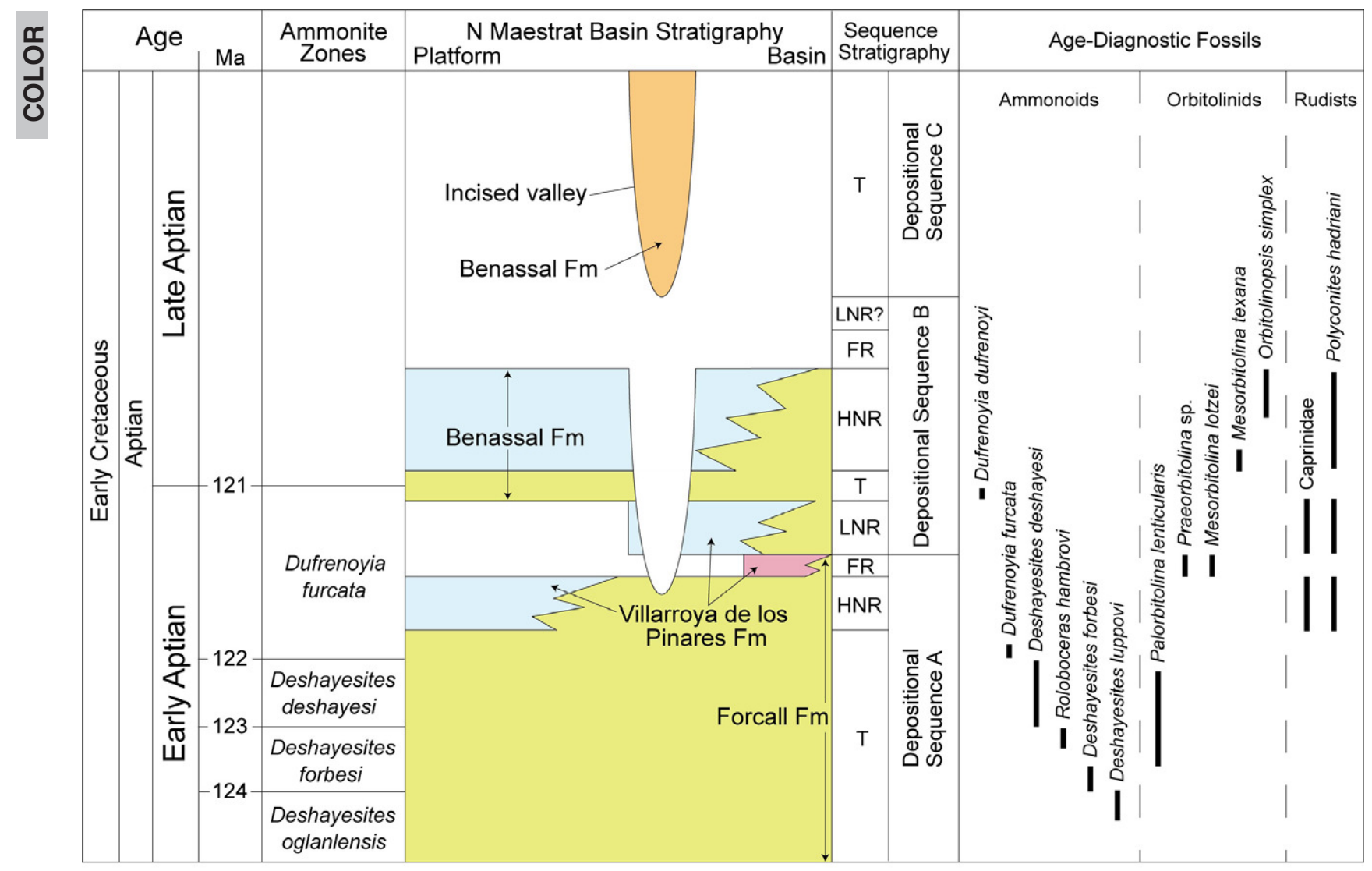

Basinal marls

Platform carbonates

Foreshore-upper shoreface deposits

Peritidal to shallow subtidal deposits

Fig. 2. Stratigraphic framework and age relations for the Aptian in the Morella Sub-basin. Local ranges of agediagnostic fossils recognized are indicated. Identified ammonite biozones are taken from Moreno-Bedmar et al. (2010). Absolute ages are from Gradstein et al. (2004).

light grey, floatstone to rudstone limestones characterized by the presence of wholly preserved rudist bivalves (Fig. 5A). The limestones display massive and tabular bedding. Rudists are commonly preserved in life position. Frequently, some species of elevator rudists such as Polyconites hadriani (Skelton et al., 2010) occur grouped in bouquets, or more rarely give rise to decimetre-thick biostromes. Scattered centimetric to decimetric corals in growth position exhibiting branching, sheet-like, platy, domal and irregular massive morphologies are also present. At times, corals display Gastrochaenolites borings, which on occasion preserve the in situ valves of the lithophagid bivalve. Skeletal fragments of rudists and corals are abundant. Saddle dolomite within rudist shells and corals occurs. Other common constituents of this lithofacies are peloids, the peyssonneliacean red alga Polystrata alba encrusting skeletal components, nerineid gastropods, other gastropods, orbitolinids, other benthic foraminifera, sessile foraminifera attached to bioclasts, serpulids, Chondrodonta, oysters and angular to sub-angular fragments of molluscs, echinoids and dasycladaceans. The skeletal components frequently appear highly bioeroded.

Also included in this lithofacies assemblage are: (i) mudstones; (ii) orbitolinid-rich limestones; (iii) coral-bearing limestones and (iv) skeletal-peloidal limestones. The mudstones constitute decimetre-thick to metre-thick massive whitish beds and include scattered orbitolinids, lituolids and other benthic foraminifera. The orbitolinid-rich limestones are light grey-coloured. These limestones have thicknesses ranging from centimetres to decimetres and exhibit floatstone to rudstone textures, which also contain miliolids, other foraminifera, peloids and angular to sub-angular fragments of molluscs. The coral-bearing limestones form decimetre-thick to metre-thick, light grey, 


\section{Key}

MFZ Maximum Flooding Zone

MFS Maximum Flooding Surface

BSFR Basal Surface of Forced Regression

RSME Regressive Surface of Marine Erosion

MRS Maximum Regressive Surface

SB Sequence Boundary

SU Subaerial Unconformity

CC Correlative Conformity

\begin{tabular}{|ll|}
$\square$ Platform lithofacies association & HNR Highstand Normal Regressive \\
$\square$ Slope lithofacies association & FR Forced Regressive \\
$\square$ Basin lithofacies association & TNR Lowstand Normal Regressive \\
\hline$\square$
\end{tabular}

Platform-detached wedge lithofacies association

Incision back-fill lithofacies association
HNR Highstand Normal Regressive

LNR Lowstand Normal Regressive

$T$ Transgressive
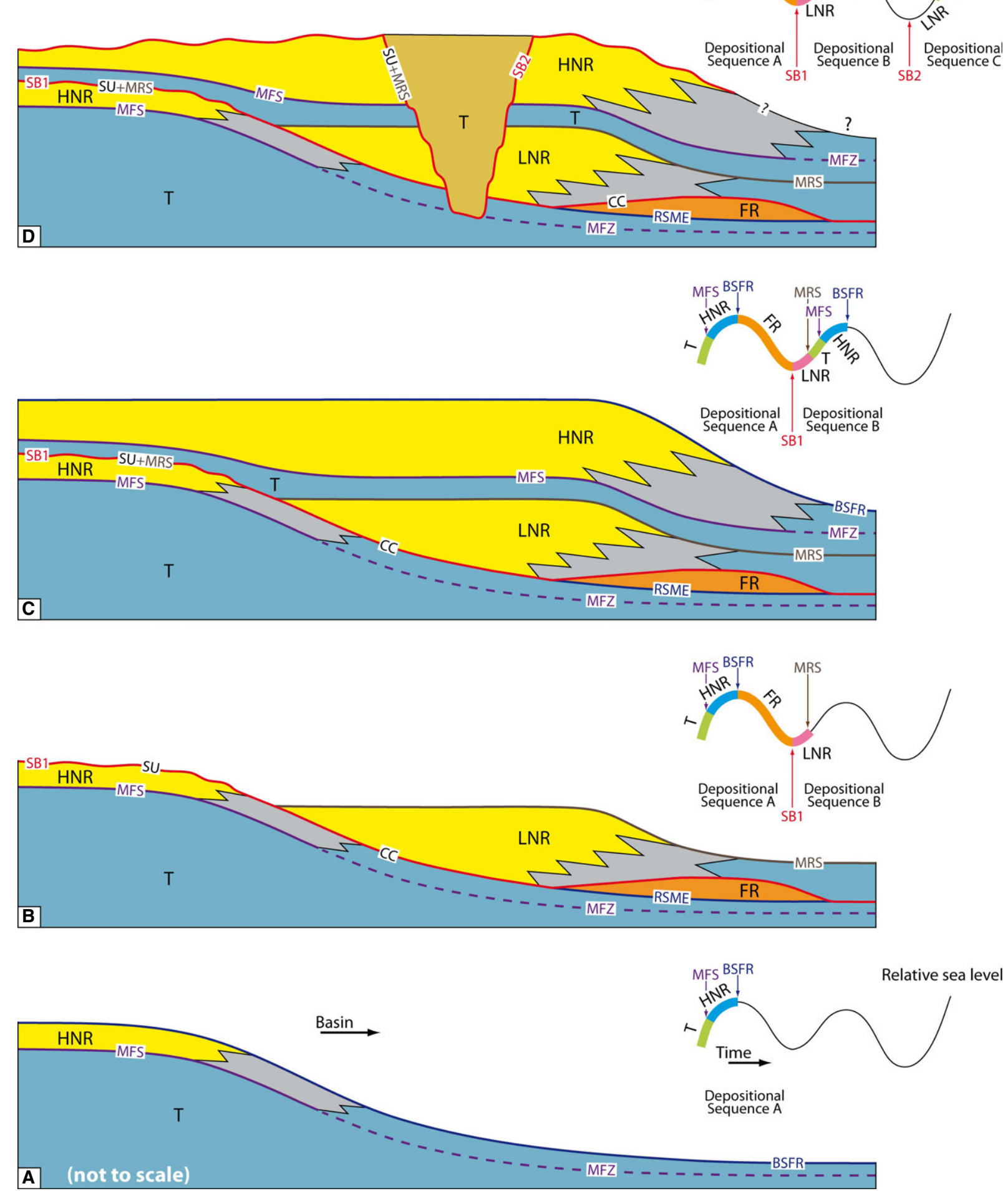

(C) 2014 The Authors. Sedimentology (C) 2014 International Association of Sedimentologists, Sedimentology 
Fig. 3. Schematic block diagrams showing the sequential evolution and lithofacies architecture in the Morella Sub-basin during the Aptian. (A) The transgressive marls of Depositional Sequence A (Forcall Formation) deposit. A maximum flooding surface separates this transgressive unit from highstand normal regressive platform carbonates (Villarroya de los Pinares Formation). The highstand platform passes basinwards to slope settings and the slopes pinch out into the basinal marls of the Forcall Formation. (B) Base level starts to fall. A basal surface of forced regression, which overlies the highstand genetic type of deposit, is generated. The highstand platform is exposed and eroded. The highstand carbonate factory shuts down. Accommodation is greatly reduced and restricted to the basin, where a distinct, forced regressive carbonate factory develops. High-energy platformdetached forced regressive wedges are deposited. As a result of base-level fall, a subaerial unconformity (Sequence Boundary 1), which passes basinwards to its marine correlative conformity, forms. The sequence boundary marks the lowest point of relative sea-level. As relative sea-level commences to rise, the available depositional space increases and a lowstand normal regressive carbonate platform corresponding to Depositional Sequence B flourishes. This platform (Villarroya de los Pinares Formation), which progrades and evolves basinwards to slope settings and then to basinal marls, downlaps over forced regressive wedges or highstand marls and onlaps the former highstand slopes. Above, a maximum regressive surface marks the end of regression. (C) With the start of transgression, the lowstand normal regressive carbonate platform drowns and evolves upwards into transgressive marls (Benassal Formation). Above the transgressive marls, a maximum flooding surface and a maximum flooding zone mark the end of transgression. As the highstand stage of normal regression begins, platform carbonates (Benassal Formation) develop. The highstand platform passes basinwards to the slopes and the slopes pinch out into basinal marls. Relative sea-level starts to fall again, and a basal surface of forced regression, which overlies the highstand genetic type of deposit of Depositional Sequence B is formed. (D) As a result of this second relative sea-level drop, the highstand platform of Depositional Sequence B is subaerially exposed and incised. The incision cuts down to Depositional Sequence A. The subaerial unconformity (Sequence Boundary 2) marks the lowest point of relative sea-level. Given that forced regressive and lowstand normal regressive deposits have not been recognized for depositional sequences B and C, respectively, these genetic units have not been outlined with their corresponding colour on the relative sea-level curve. During the transgressive stage of Depositional Sequence C, peritidal to shallow subtidal deposits fill the incision. With the start of transgression, the maximum regressive surface is superposed onto the subaerial unconformity (Sequence Boundary 2) giving rise to a composite surface (SU + MRS).

nodular beds. The corals are found in growth position and corresponded to level-bottom communities, which display an unbound growth fabric with irregular massive, platy and domal centimetric to decimetric forms. Scattered rudist shells, as well as peloids, benthic foraminifera and fragments of echinoids and molluscs are also common components of these coral-rich levels. The skeletal-peloidal limestones correspond to light grey tabular beds. Occasionally, these deposits display cross-bedding features. The beds have thicknesses ranging from centimetres to decimetres and exhibit poorly sorted to moderately sorted packstone to grainstone textures. Peloids are abundant. Orbitolinids, miliolids, other benthic foraminifera, Polystrata alba encrusting bioclasts and angular to rounded fragments of oysters, other bivalves, gastropods, bryozoans, corals and echinoids, dominate the skeletal constituents. Rarely, wholly preserved Toucasia specimens are found at the top of the beds of this sub-lithofacies.

\section{Slope lithofacies association}

This lithofacies assemblage is mainly characterized by centimetre-thick to metre-thick, light grey, nodular-bedded deposits shed from the platform top. Ochre marly limestone lithologies are also common. On occasion, the beds display channel-filled sedimentary bodies, slump scars and erosive surfaces. The limestones exhibit very poorly sorted floatstone and rudstone textures, which mainly contain fragments of rudists and corals. The fragmented skeletal parts are frequently bioeroded and mainly show angular edges. Decimetric wholly preserved isolated coral colonies in growth position are also important constituents of this lithofacies. Similar coral populations have been analysed for the same time interval in slope settings from the western Maestrat Basin (Bover-Arnal et al., 2012). The colonies display platy (Fig. 5B), sheet-like, branching, domal and irregular massive morphologies. Gastrochaenolites on corals are frequent. Rhynchonellid brachiopods, and elevator rudists such as Polyconites hadriani (Skelton et al., 2010) in life position, which sometimes show a clustered growth, are also occasionally present. Other important accompanying components of the lithofacies are the same as those detailed in the platform lithofacies association for the floatstone and rudstone limestones dominated by rudists. 


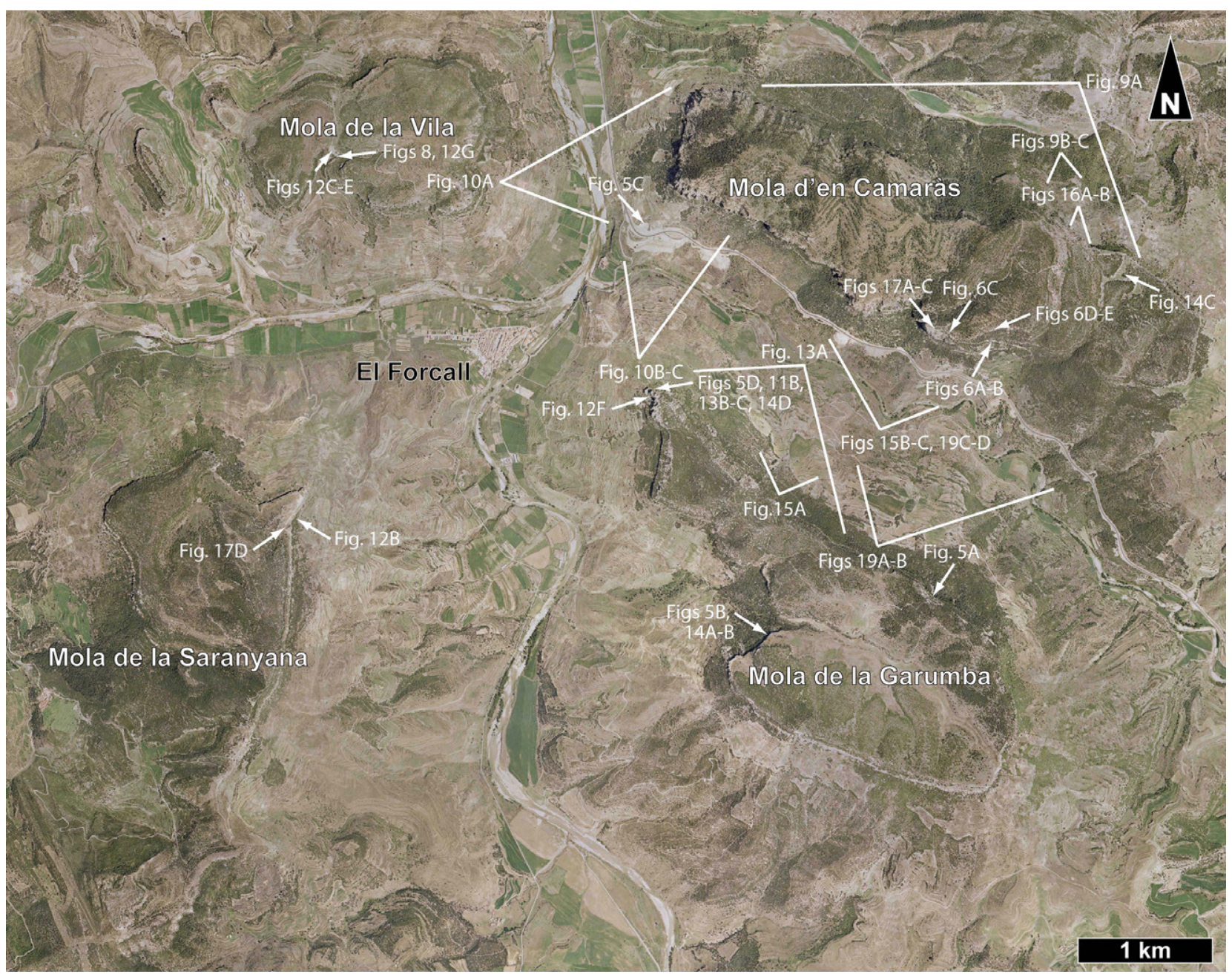

Fig. 4. Aerial photograph of the Mola d'en Camaràs, Mola de la Vila, Mola de la Saranyana and Mola de la Garumba that surround the village of El Forcall. The location of the outcrops and lithofacies shown in Figs 5, 6, 8, 9, 10,11B, 12B to G, 13 to 17 and 19 is indicated. Source of aerial photograph: SIGPAC photographs of the Spanish Ministry of Agriculture, Food and Environment.

Orbitolinid-rich centimetre-thick to decimetrethick, light grey, limestones and marly limestones are also on occasion found in slope settings. These levels exhibit floatstone and rudstone textures and besides orbitolinids, include peloids, miliolids, other foraminifera and angular to sub-rounded fragments of molluscs.

\section{Basin lithofacies association}

The lithofacies association is composed of bluish and ochre marls up to tens of metres-thick with occasional interbedded centimetre-thick to decimetre-thick marly limestones and carbonate nodules. The ochre colour is due to oxidation. The macrofossils are dominated by rhynchonellid and terebratulid brachiopods, ammonites, oysters and other bivalves (Fig. 5C). Other common macrobiota present are serpulids, belemnites, vermetid gastropods, other gastropods, crinoids, irregular echinoids and fragments of decapods. Nannoconids, and benthic and planktonic foraminifera, also occur. Pyritized skeletal components are frequent. The marl lithology together with the fossil content, which is characterized by the presence of ammonoids, indicates deeper neritic environments when compared to the lithofacies assemblages deposited in platform and slope settings.

\section{Platform-detached wedge lithofacies association}

Ochre and light grey decimetre-thick to metrethick poorly sorted to moderately sorted 

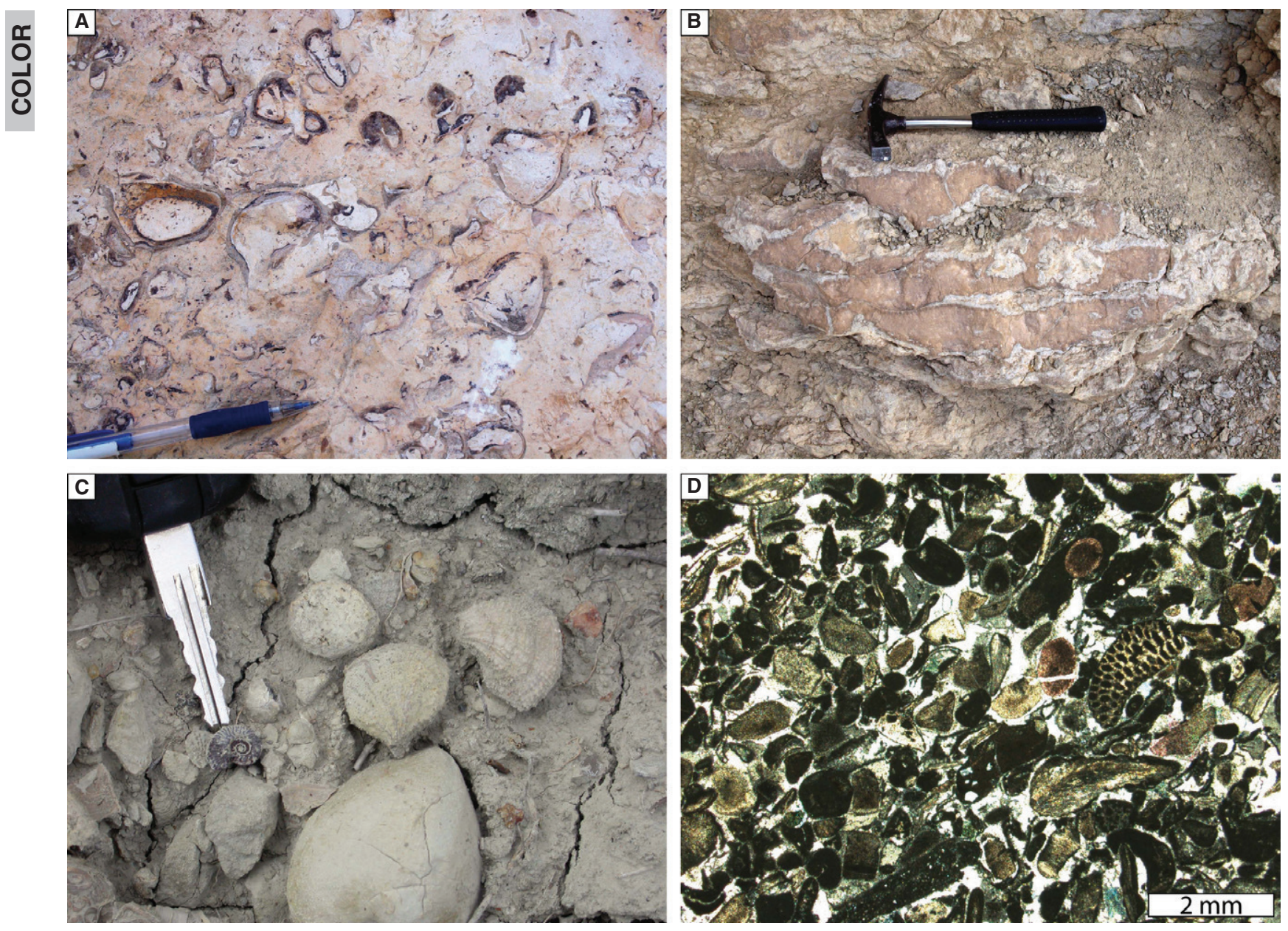

Fig. 5. Platform, slope, basin and platform-detached wedge lithofacies associations. (A) Detail of a floatstone texture containing small requieniid rudists and monopleurids. Highstand platform of Depositional Sequence B, Benassal Formation, Late Aptian, Mola de la Garumba. Visible part of pen $=12 \cdot 2 \mathrm{~cm}$. (B) Detail of wholly preserved platy corals in growth position embedded in nodular marly limestones in slope settings. Lowstand platform of Depositional Sequence B, Villarroya de los Pinares Formation, Early Aptian, Mola de la Garumba. Hammer length $=32 \mathrm{~cm}$. (C) Close-up view of two specimens of Plicatula placunea (centre), of an unidentified large bivalve (bottom centre) and of a small Deshayesites deshayesi specimen, which is pointed by the key. Transgressive basinal marls of Depositional Sequence A, Forcall Formation, Early Aptian, Mola d'en Camaràs. Visible part of key $=4.6 \mathrm{~cm}$. (D) Photomicrograph of a moderately sorted grainstone texture with abundant peloids and fragments of echinoids. Note the presence of a fragment of a bryozoan colony (centre right). The microfacies is collected from the level with trough cross-bedding shown in Fig. 11B. Forced regressive unit of Depositional Sequence A, Villarroya de los Pinares Formation, Early Aptian, Mola de la Garumba.

grainstones (Fig. 5D) form this lithofacies. The limestones are massive or display low-angle cross-bedding, trough cross-bedding or plane-parallel stratification. Burrows occur. The main constituents of the lithofacies are peloids, coated grains, orbitolinids, other benthic foraminifera, small nerineid gastropods and sub-rounded to rounded fragments of oysters, other bivalves, gastropods, echinoids, siphonaceous green algae, decapods, serpulids and bryozoans. The orbitolinids frequently show agglutinated silt-sized quartz particles. Saddle dolomite and bioerosional structures within the bioclasts are occasionally present. The presence of grainstone textures and sedimentary structures such as plane-parallel stratification, and low-angle and trough cross-bedding indicates a sedimentary environment most probably in the foreshore-upper shoreface (e.g. Chakraborty \& Paul, 2008).

\section{Incision back-fill lithofacies association}

This lithofacies assemblage mainly includes centimetre-thick to tens of metres-thick 
ㅇํํ
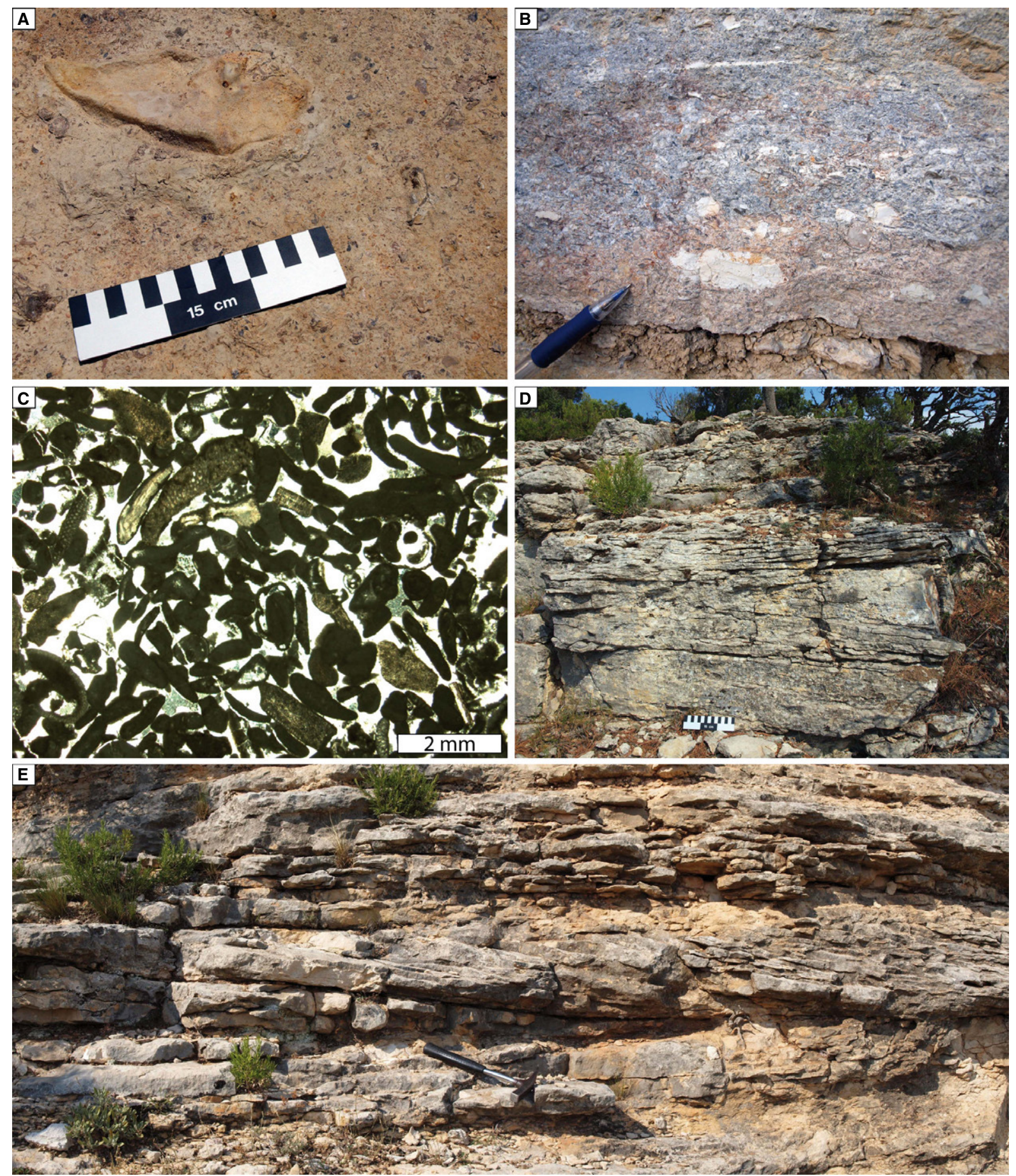

Fig. 6. Incision back-fill lithofacies association. (A) Ochre limestone exhibiting a floatstone to rudstone texture with abundant fragments of oysters. Note the presence of decimetre-sized lithoclast (upper left). Transgressive unit of Depositional Sequence C, Benassal Formation, Late Aptian, Mola d'en Camaràs. (B) Rudstone texture dominated by fragments of oysters. Note the presence of mud pebbles and mud drapes. Transgressive unit of Depositional Sequence C, Benassal Formation, Late Aptian, Mola d'en Camaràs. Visible part of pen $=7 \cdot 5 \mathrm{~cm}$. (C) Photomicrograph of a moderately sorted grainstone texture, which includes abundant peloids, orbitolinids and skeletal fragments of oysters, gastropods and echinoids. Transgressive unit of Depositional Sequence C, Benassal Formation, Late Aptian, Mola d'en Camaràs. (D) Herring-bone cross-stratification formed by aggradation during alternate tidal flow. Transgressive unit of Depositional Sequence C, Benassal Formation, Late Aptian, Mola d'en Camaràs. Ruler $=15 \mathrm{~cm}$. (E) Outcrop view of a level with tidal bundles (centre). Transgressive unit of Depositional Sequence C, Benassal Formation, Late Aptian, Mola d'en Camaràs. Hammer length $=32 \mathrm{~cm}$. 
intervals of white marls, decimetre-thick ochre nodular marly limestones and centimetre-thick to metre-thick limestones. Scattered oyster specimens are occasionally embedded within the marls. In the marly limestones, oysters are abundant and frequently display a clustered growth. Rarely, scleractinian colonies in growth position occur. The limestones exhibit different textures and bedding patterns. These comprise (i) white nodular mudstones, which occasionally display Thalassinoides, and contain scattered biseriate foraminifera, miliolids and fragments of echinoids; (ii) light grey, occasionally burrowed, wackestone to packstone textures with peloids, orbitolinids, other foraminifera and fragments of serpulids, gymnocodiacean algae, echinoids, oysters and other molluscs; (iii) light grey and ochre floatstone to rudstone textures dominated by fragments of oysters, but also including rudist shells, fragments of other molluscs and echinoids, benthic foraminifera, peloids, unidentified burrows, lithoclasts (Fig. 6A) and mud pebbles and mud drapes (Fig. 6B) and (iv) ochre and light grey poorly sorted to well-sorted grainstones (Fig. 6C), which exhibit cross-bedding, herringbone cross-stratification (Fig. 6D), tidal bundles (Fig. 6E) and burrows, and contain abundant peloids, miliolids, orbitolinids, other benthic foraminifera and fragments of echinoids, decapods, algae, bryozoans, oysters, gastropods and other molluscs. The grainstones with hydrodynamic structures mainly characterize the upper part of the incision back-fill sedimentary succession.

Sedimentary features such as mud drapes and mud pebbles, the presence of lithoclasts, sedimentary structures such as tidal bundles, bi-directional current indicators and the fossil content, which is dominated by oysters, are in agreement with a peritidal succession. The occurrence of rare stratigraphic levels containing rudist bivalves or coral colonies in life position indicates occasional shallow subtidal conditions.

\section{SEQUENCE STRATIGRAPHIC INTERPRETATION}

The Aptian record of the northern Maestrat Basin is subdivided into three depositional sequences ( $\mathrm{A}, \mathrm{B}$ and $\mathrm{C}$ ) based on the distribution of lithofacies, architecture of the strata and the identification of sequence stratigraphic surfaces. A 2D continuous platform-to-basin conceptual profile displaying the sedimentary response for each depositional sequence of the long-term relative sea-level evolution is provided in Fig. 3. Figure 7 displays the position of each hillock ('Mola') studied within this conceptual model. A representative schematic log of the Mola de la Vila showing the vertical lithofacies evolution, the stratigraphic position

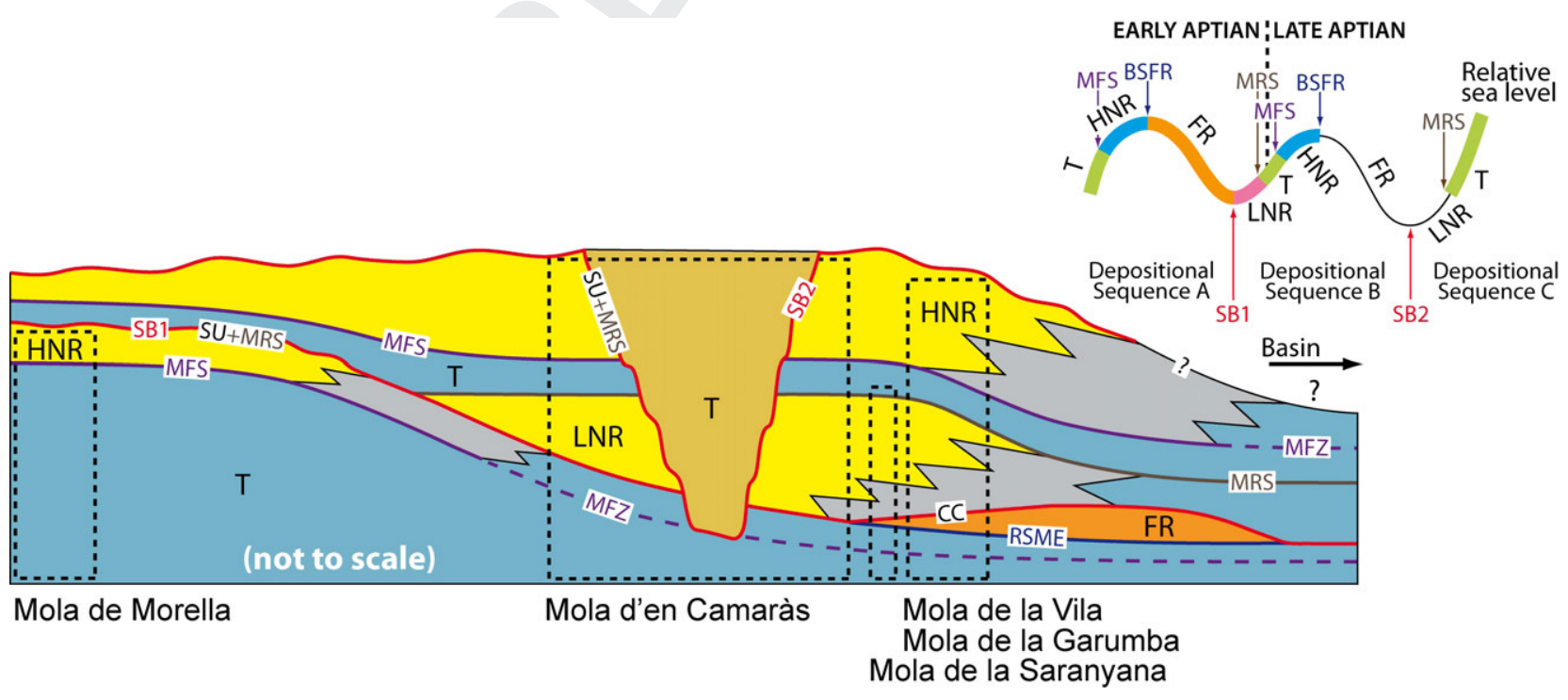

Fig. 7. Schematic block diagram showing the situation of the preserved sedimentary successions corresponding to the five hillocks studied (Mola de Morella, Mola d'en Camaràs, Mola de la Saranyana, Mola de la Vila and Mola de la Garumba) within the conceptual model provided in Fig. 3. 


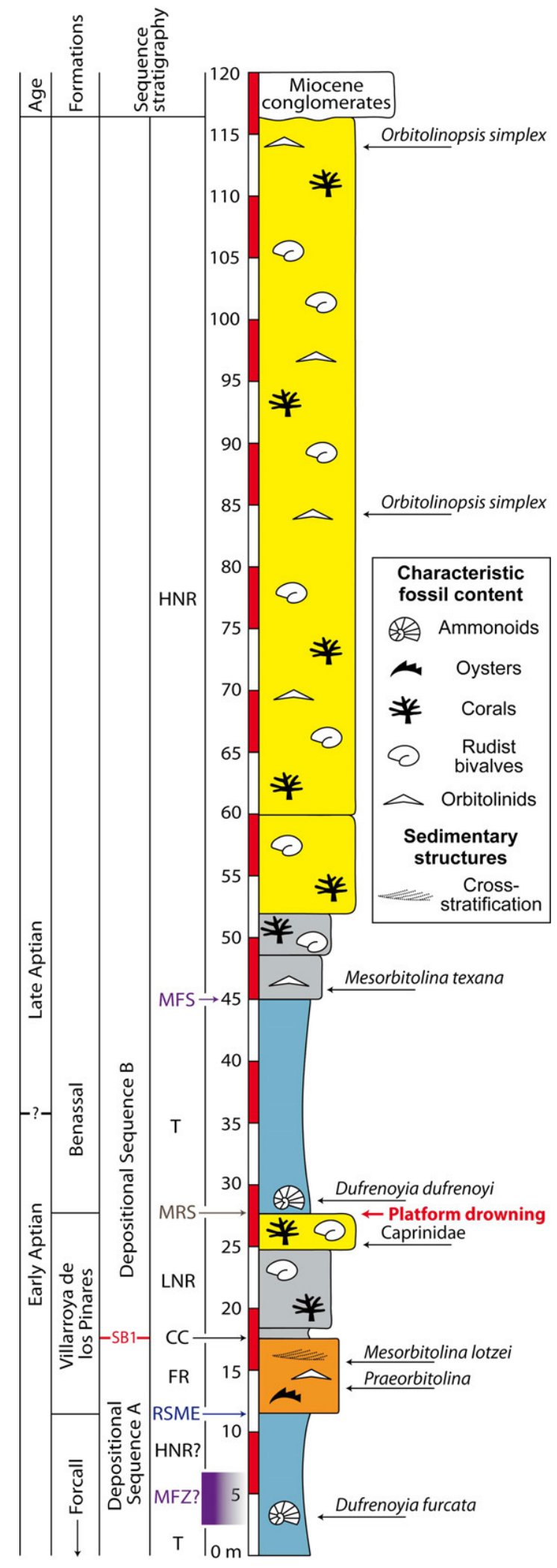

of the age-diagnostic fauna and the sequence stratigraphic interpretation is provided in Fig. 8.
Fig. 8. Representative schematic log of the Mola de la Vila showing the vertical lithofacies evolution during depositional sequences $\mathrm{A}$ and $\mathrm{B}$, the stratigraphic position of the age-diagnostic fauna collected and the sequence stratigraphic interpretation. See Figs 3 and 4 for key and for geographical position of the section, respectively.

\section{Depositional Sequence A}

Transgressive genetic type of deposit

The transgressive unit comprises the basin lithofacies association (Figs 3A and 5C) and corresponds to the marls of the Forcall Formation (Fig. 2). During rapid creation of accommodation, lime mud and fine-grained siliciclastic particles were transported by suspension from proximal platform and coastal settings to the basin, and mixed to form the marls. The marl interval (Figs 9 and 10) is $>3100 \mathrm{~m}$ thick and contains ammonite taxa belonging to the four Early Aptian Zones: Deshayesites oglanlensis, Deshayesites forbesi, Deshayesites deshayesi (Fig. 5C) and Dufrenoyia furcata (see Moreno-Bedmar et al., 2010 and Garcia et al., 2014 for species). The presence of the large benthic foraminifer Palorbitolina lenticularis distinguishes the lower part of the Forcall Formation, whereas the brachiopods Burrirhynchia miliani and Sellithyris sella, the bivalve Plicatula placunea (Fig. 5C) and the irregular echinoid Toxaster collegnoi are characteristic of the upper part of these transgressive marls.

\section{Highstand normal regressive genetic type of} deposit

A decrease in the rate of relative sea-level rise forced the carbonate production zone to prograde into the basin. This prograding carbonate system constitutes a highstand normal regressive genetic unit (Fig. 3A). The boundary between the transgressive and normal regressive deposits corresponds to an interpreted maximum flooding surface, which is placed at the contact between underlying marls of the Forcall Formation and overlying highstand platform carbonates of the Villarroya de los Pinares Formation (Figs 2 and 3A). In seismic stratigraphy, the maximum flooding surface is often interpreted as the surface downlapped by highstand prograding clinoforms (Catuneanu et al., 2011). This highstand platform, which is locally preserved at the Mola de Morella (Figs 1C, 7 and 11A), progrades and downlaps over basin marls 


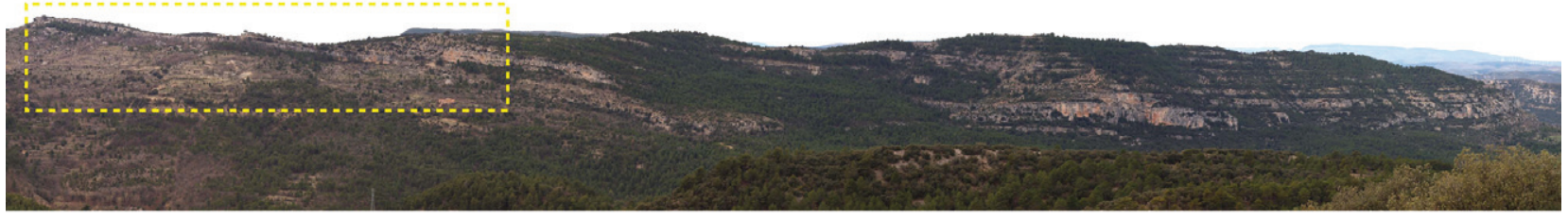

B

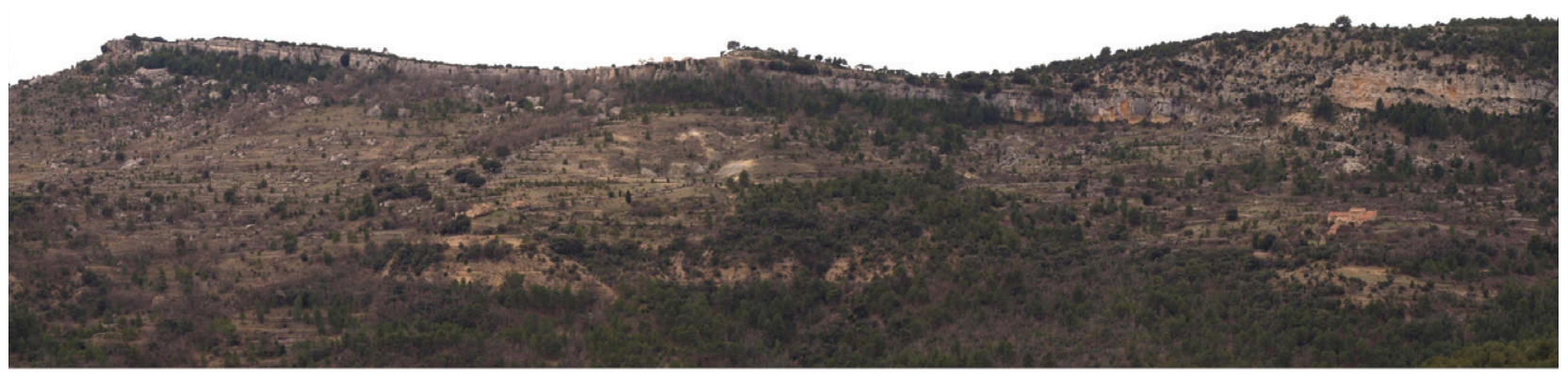

C

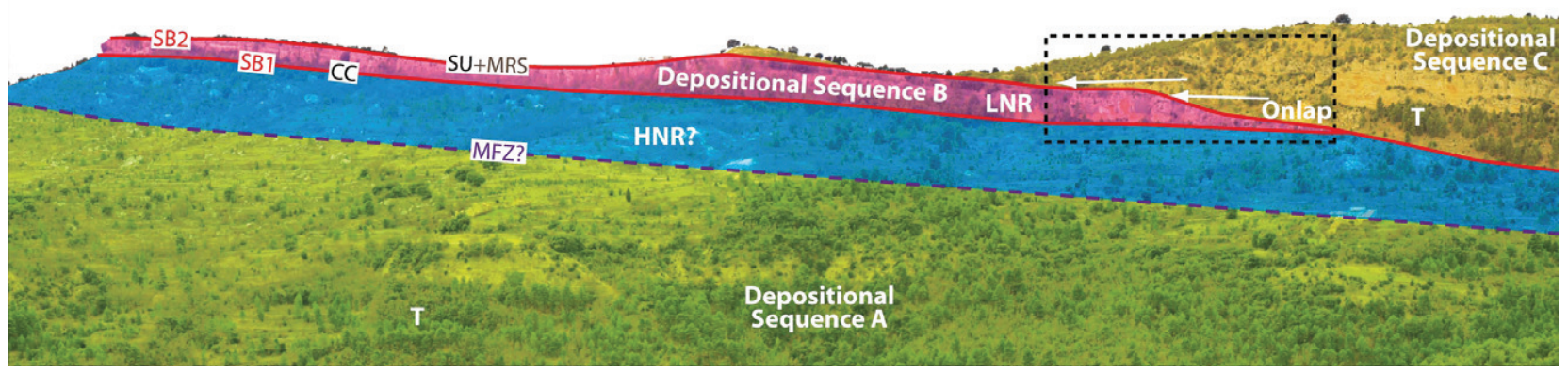

Fig. 9. Sequence stratigraphy. (A) Photomosaic of the north-eastern face of the Mola d'en Camaràs. The area outlined in yellow corresponds to the close-up view provided in (B). Width of image is ca $2 \mathrm{~km}$. (B) Close-up view of (A). (C) Sequence stratigraphic interpretation of (B). Note how the lowstand platform (Villarroya de los Pinares Formation) of Depositional Sequence B is incised and onlapped by the transgressive deposits of Depositional Sequence C. See Fig. 3 for key. A close-up view of the area outlined in black is shown in Fig. 16.

(Fig. 3A), indicating that it is indeed a maximum flooding surface.

The carbonates of the Mola de Morella correspond to proximal platform settings. These platform-top deposits passed basinwards to slopes, and these pinched out into the basin marls of the Forcall Formation (Figs 3A and 7). Due to the discontinuous nature of the outcrops and the absence of limestone beds as stratigraphic guides within the upper part of the Forcall Formation, the maximum flooding surface cannot be mapped towards the basin (at the other hillocks; Fig. 7). Therefore, in basin settings, the concept of maximum flooding zone will be applied (see Strasser et al.,
1999). The maximum flooding zone is interpreted as being within the upper part of the Forcall Formation (Figs 3A, 8, 9C and 10C), given that the uppermost part of the marl succession corresponds to basin sediments deposited during the highstand stage of relative sealevel (Fig. 3A).

Highstand carbonates of the Mola de Morella (Figs 1C, 7 and 11A) are $c a 80 \mathrm{~m}$ thick. The top of this platform succession is not preserved due to Neogene and present-day erosion. Therefore, signs of subaerial exposure of Aptian age cannot be recognized. The highstand platform contains abundant Chondrodonta, as well as polyconitid, requieniid and caprinid rudists (Fig. 12A), 

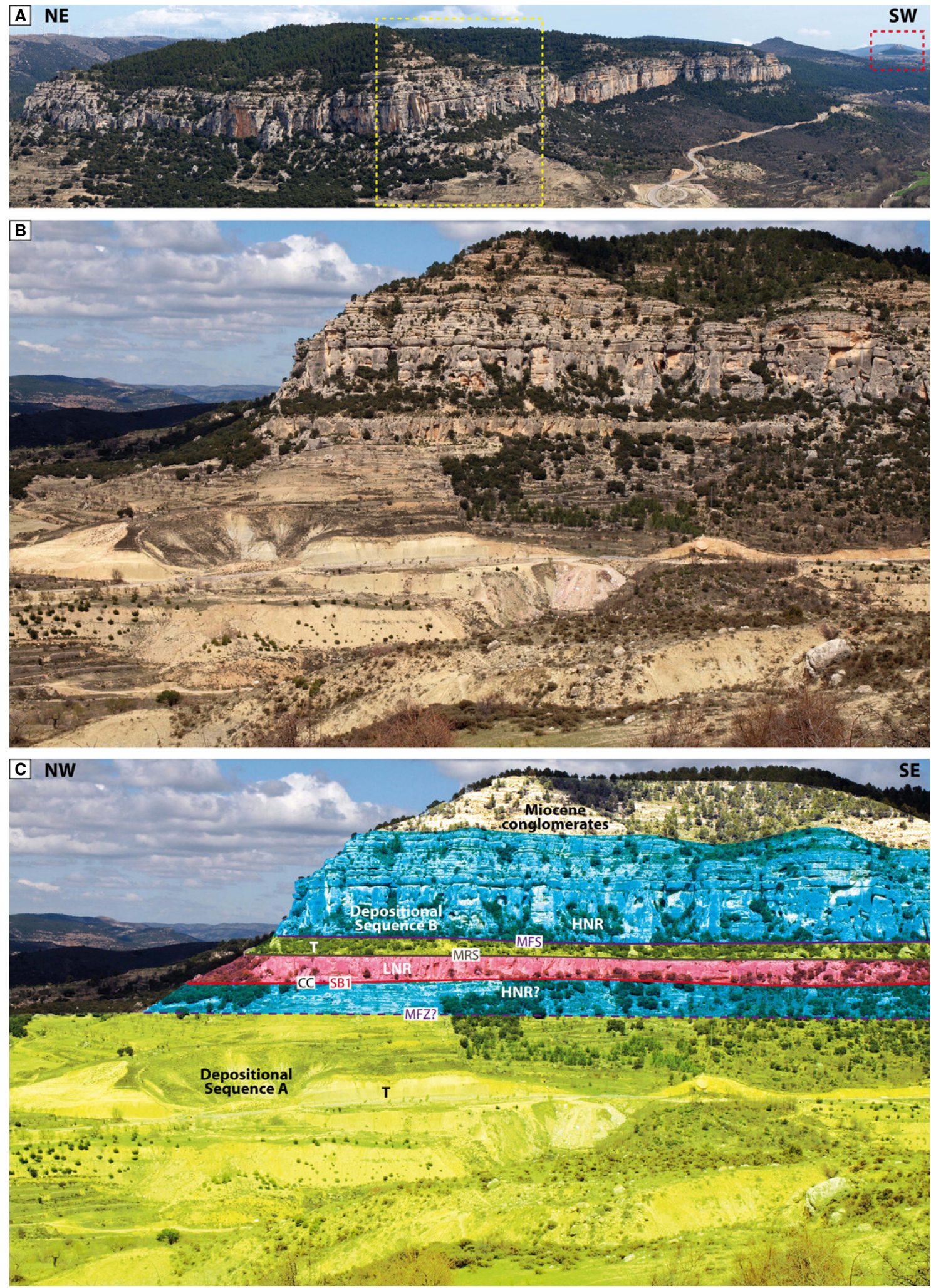

Fig. 10. Sequence stratigraphy. (A) Photomosaic of the north-western face of the Mola d'en Camaràs. The areas outlined in yellow and red correspond, respectively, to the close-up view provided in panel (B) and to the situation of the highstand normal regressive platform of Depositional Sequence A shown in Fig. 11A. Width of image is $\mathrm{Ca}$ $1.5 \mathrm{~km}$. (B) Close-up view of (A). (C) Sequence stratigraphic interpretation of (B). Note the significant thickness exhibited by the transgressive unit (marls of the Forcall Formation) of Depositional Sequence A. See Fig. 3 for key. 

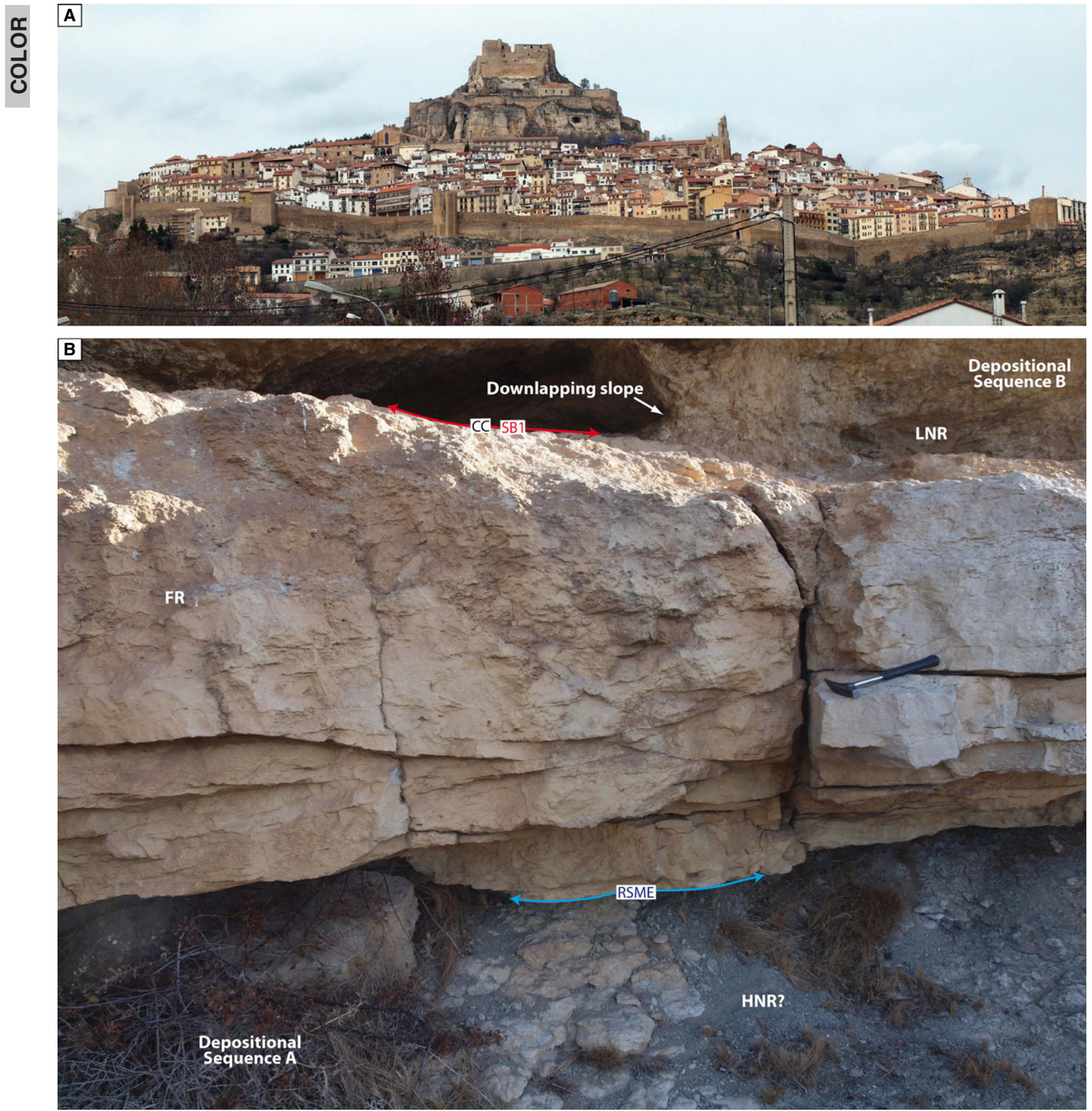

Fig. 11. Highstand normal regressive platform and forced regressive deposits of Depositional Sequence A (Villarroya de los Pinares Formation). (A) Panoramic view of the village of Morella with its castle built on top of the preserved highstand normal regressive platform carbonates of Depositional Sequence A. Width of image is ca $700 \mathrm{~m}$. (B) Outcrop view of a platform-detached wedge showing trough cross-bedding. Forced regressive unit of Depositional Sequence A, Villarroya de los Pinares Formation, Mola de la Garumba. Below the platform-detached wedge, highstand normal regressive marls of Depositional Sequence A (Forcall Formation, Early Aptian) are visible. The downlapping slopes of the lowstand normal regressive platform of Depositional Sequence B (Villarroya de los Pinares Formation, Early Aptian) are observable at the top of the image. See Fig. 3 for key. Hammer length $=32 \mathrm{~cm}$.

probably including Caprina parvula. The presence of Caprinidae indicates an Early Aptian age (Skelton \& Gili, 2012).
Forced regressive genetic type of deposit The highstand normal regressive platform of the Mola de Morella was subaerially exposed and 

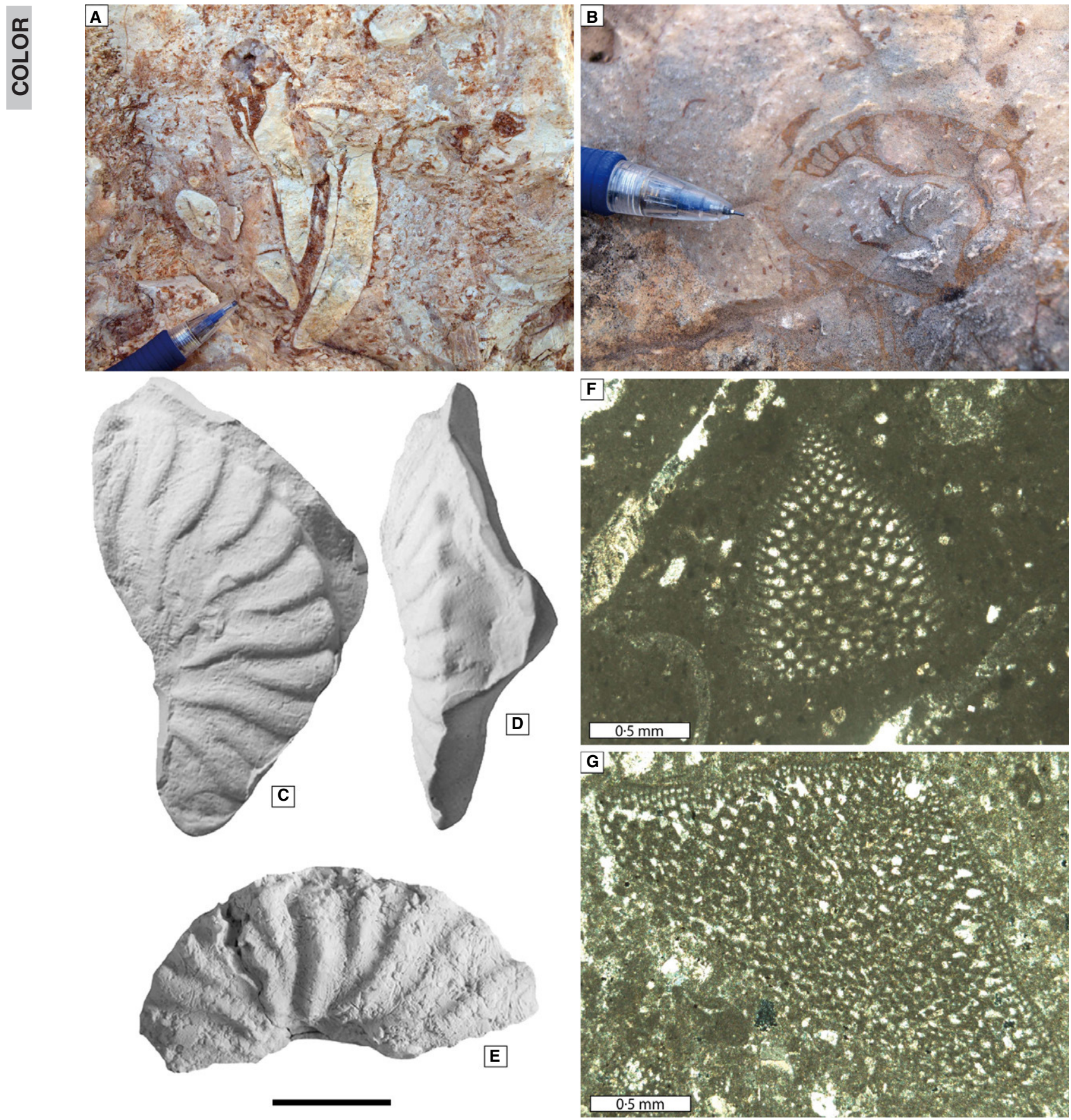

Fig. 12. Age-diagnostic fossils. (A) Detail of mutually attached caprinid rudists. Platform lithofacies association, highstand normal regressive deposits of Depositional Sequence A, Villarroya de los Pinares Formation, Early Aptian, Mola de Morella. Visible part of pen $=3.3 \mathrm{~cm}$. (B) Close-up view of a section of a caprinid rudist (Caprina aff. parvula). Platform lithofacies association, lowstand normal regressive unit of Depositional Sequence B, Villarroya de los Pinares Formation, Early Aptian, Mola de la Garumba. Visible part of pen $=2 \cdot 3 \mathrm{~cm}$. (C, D) Dufrenoyia dufrenoyi, lateral and ventral views of the specimen PUAB (Coleccions de Paleontologia de la Universitat Autònoma de Barcelona) 88390. Basin lithofacies association, transgressive deposits of Depositional Sequence B, Benassal Formation, Early Aptian, Mola de la Vila. Scale bar: $1 \mathrm{~cm}$. (E) Dufrenoyia dufrenoyi, lateral view of the specimen PUAB 88784. Basin lithofacies association, transgressive unit of Depositional Sequence B, Benassal Formation, Early Aptian, Mola de la Vila. Scale bar: $1 \mathrm{~cm}$. (F) Orbitolinopsis simplex. Platform lithofacies association, highstand normal regressive platform of Depositional Sequence B, Benassal Formation, Late Aptian, Mola de la Garumba. (G) Mesorbitolina texana. Platform lithofacies association, highstand deposits of Depositional Sequence B, Benassal Formation, Late Aptian, Mola de la Garumba. 

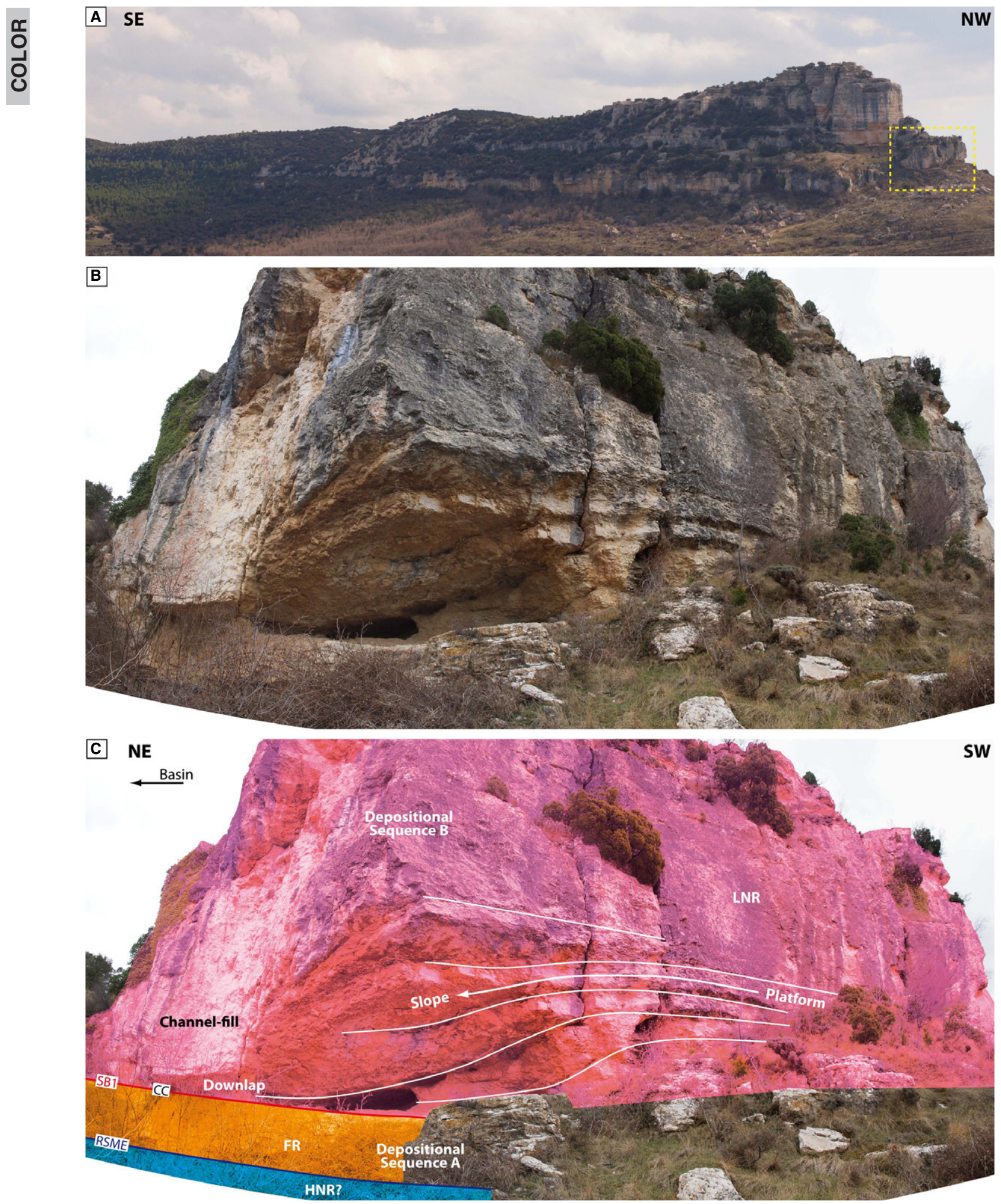

Fig. 13. Sequence stratigraphy. (A) Photomosaic of the north-eastern face of the Mola de la Garumba. The area outlined in yellow corresponds to the close-up view displayed in (B). Width of image is $c a 1.9 \mathrm{~km}$. (B) Close-up view of (A). (C) Sequence stratigraphic interpretation of (B). Note the channel-fill deposits exhibited by the lowstand platform at the Mola de la Garumba. The channel drained towards the north. Note also, how the lowstand platform of Depositional Sequence B passes laterally from platform to slope settings, and how these lowstand slopes downlap over a forced regressive wedge of Depositional Sequence A. See Fig. 3 for key.

(C) 2014 The Authors. Sedimentology (C) 2014 International Association of Sedimentologists, Sedimentology 

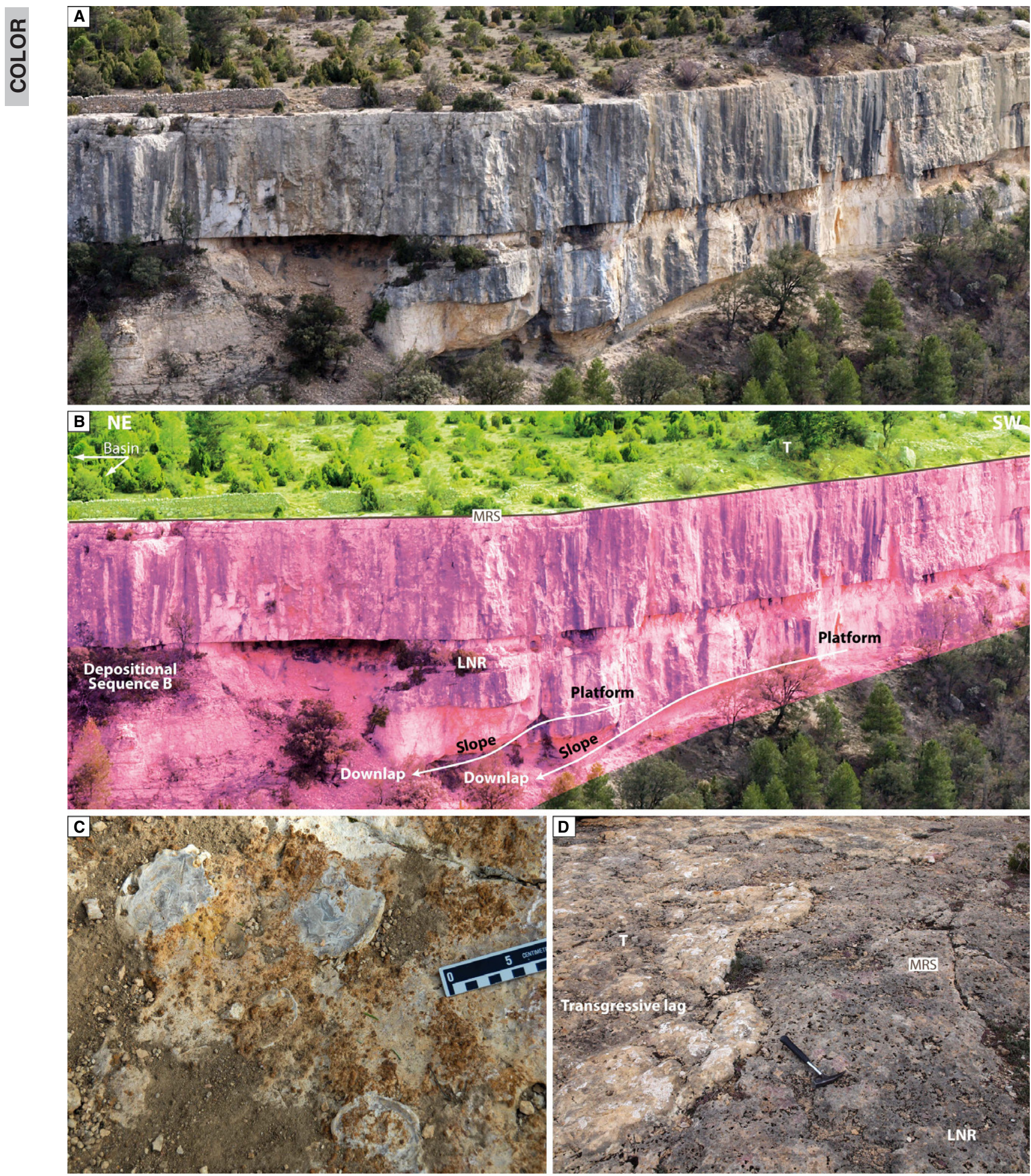

Fig. 14. Stratal geometries and drowning of the lowstand normal regressive platform of Depositional Sequence B. (A) Outcrop view of the south-western part of the Mola de la Garumba. Width of image is ca $50 \mathrm{~m}$. (B) Sequence stratigraphic interpretation of (A). Note the prograding geometries displayed by the lowstand platform, and how the in situ platform lithofacies pass basinwards to slope settings. On top of the platform, the maximum regressive surface marks the drowning of the platform, which is buried by transgressive basin marls. (C) Close-up view of three oysters encrusting the maximum regressive surface, which exhibits an iron crust. Mola d'en Camaràs. (D) Detail of the transgressive lag present in the Mola de la Garumba. Note how the transgressive lag accommodates over an irregular maximum regressive surface. See Fig. 3 for key. Hammer length $=32 \mathrm{~cm}$. 

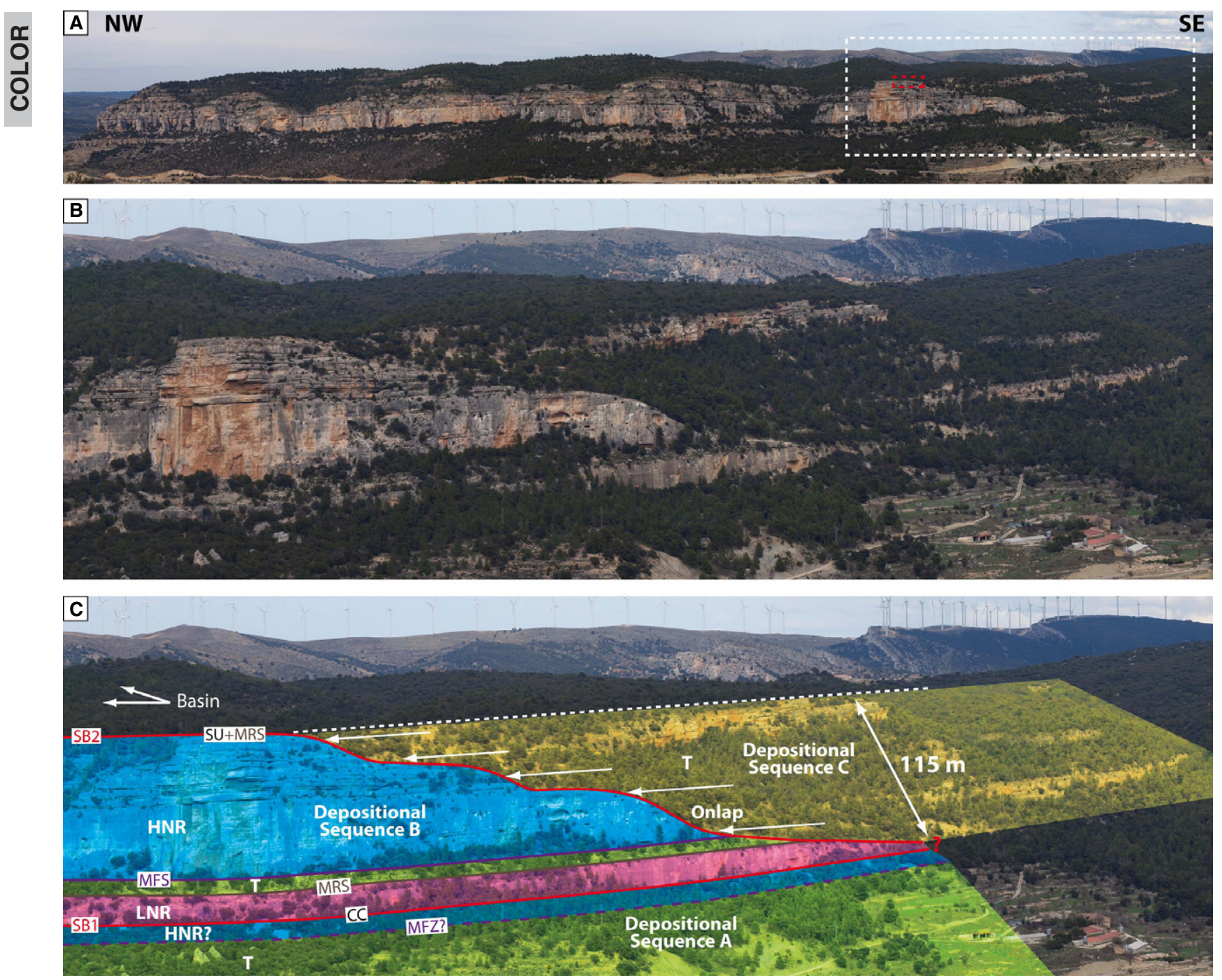

Fig. 15. Sequence stratigraphy. (A) Photomosaic of the south-western face of the Mola d'en Camaràs. The area outlined in white corresponds to the close-up view displayed in (B). The area outlined in red is enlarged in Fig. 17A. Width of image is ca $3.3 \mathrm{~km}$. (B) Close-up view of (A). (C) Sequence stratigraphic interpretation of (B). In this image, the incision down-cuts the entire Depositional Sequence B. Note also the stepped shape (strath terraces) displayed by the unconformable surface, which corresponds to Sequence Boundary 2, and how the transgressive strata of Depositional Sequence C onlap this surface. See Fig. 3 for key.

shutdown as a result of base-level fall (Figs 3B and 7). During falling relative sea-level, the area available for carbonate production and accumulation was progressively reduced and shifted basinwards, where detached skeletal wedges were deposited on top of basin marls of the Forcall Formation (Figs 3B, 7, 8, 11B and 13). These forced regressive deposits belong to the Villarroya de los Pinares Formation (Fig. 2) and are made up of the platform-detached wedge lithofacies association (Figs 3B, 5D and 11B). Biota identified at species or genus level include Choffatella decipiens, Lenticulina sp., Praeorbitolina sp., Mesorbitolina lotzei and Boueina hochstetteri. The presence of
Praeorbitolina and Mesorbitolina lotzei implies an Early Aptian age (Schroeder et al., 2010; Cherchi \& Schroeder, 2012). Forced regressive deposits are only preserved in the Mola de la Vila, Mola de la Garumba and Mola de la Saranyana (Figs 1C, 4, 7, 8, 11B and 13).

The detached wedges are bound below by regressive surfaces of marine erosion and above by the marine correlative conformity of the subaerial unconformity (Figs 3B, 7, 8, 11B and 13C). The regressive surfaces of marine erosion were formed during base-level fall by wave and sediment scouring of the highstand basin deposits. The correlative conformity marks the lowest point 

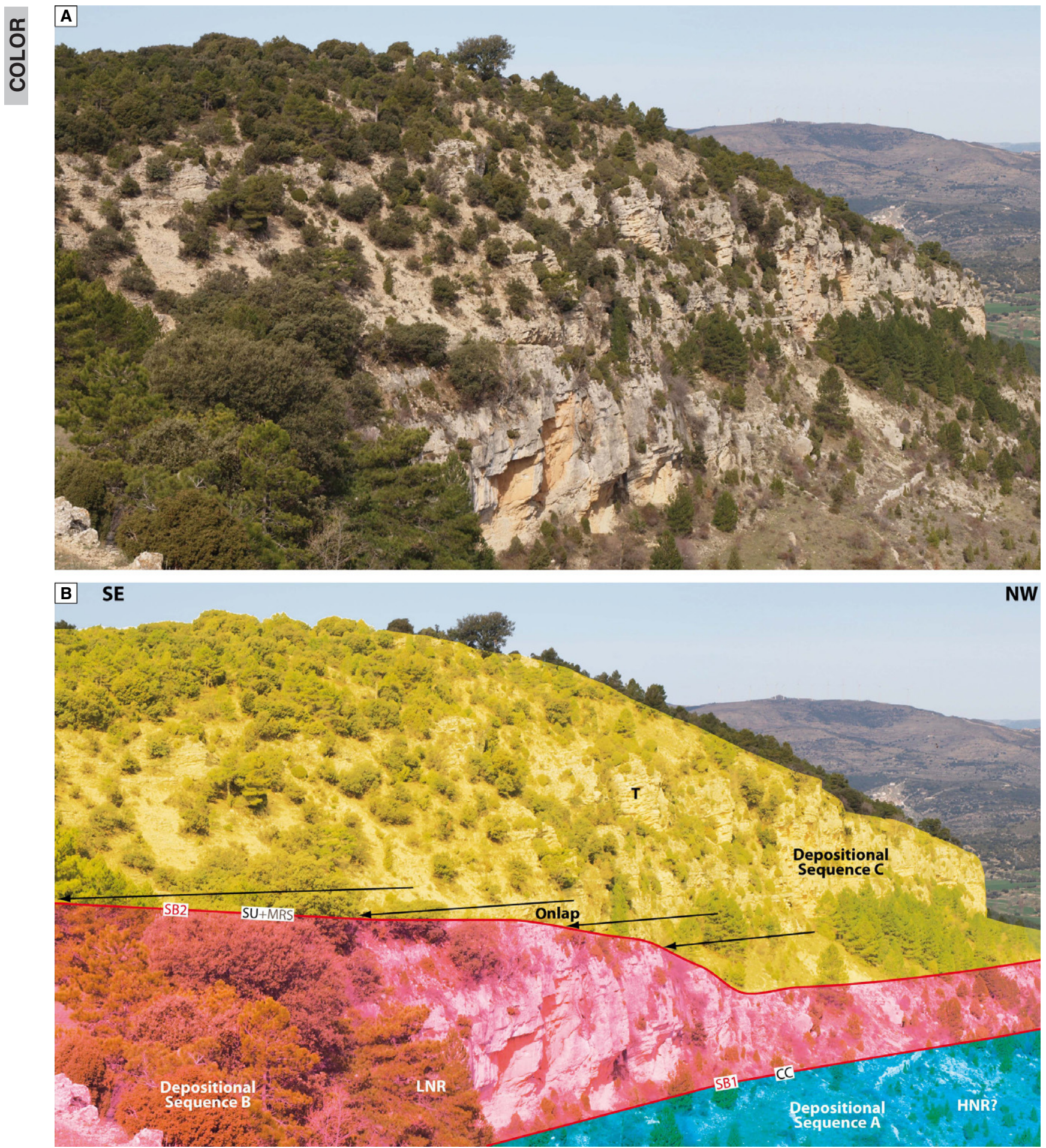

Fig. 16. Sequence stratigraphy. (A) Close-up view of Fig. 9C. North-eastern face of the Mola d'en Camaràs. Cliff is ca $50 \mathrm{~m}$ height. (B) Sequence stratigraphic interpretation of (A). In this view, the erosional surface cuts the Aptian deposits down to the lowstand carbonates of Depositional Sequence B. Note how the unconformable surface (Sequence Boundary 2) displays a stepped morphology (strath terraces) and how the transgressive deposits of Depositional Sequence C onlap this surface. See Fig. 3 for key.

of relative sea-level, and thus the most basinwards extension of the subaerial unconformity. The subaerial unconformity and its marine correlative conformity bound depositional sequences $\mathrm{A}$ and $\mathrm{B}$, and correspond to Sequence Boundary 1 (Figs 3B, 7, 8, 9C, 10C, 11B and 13C). 

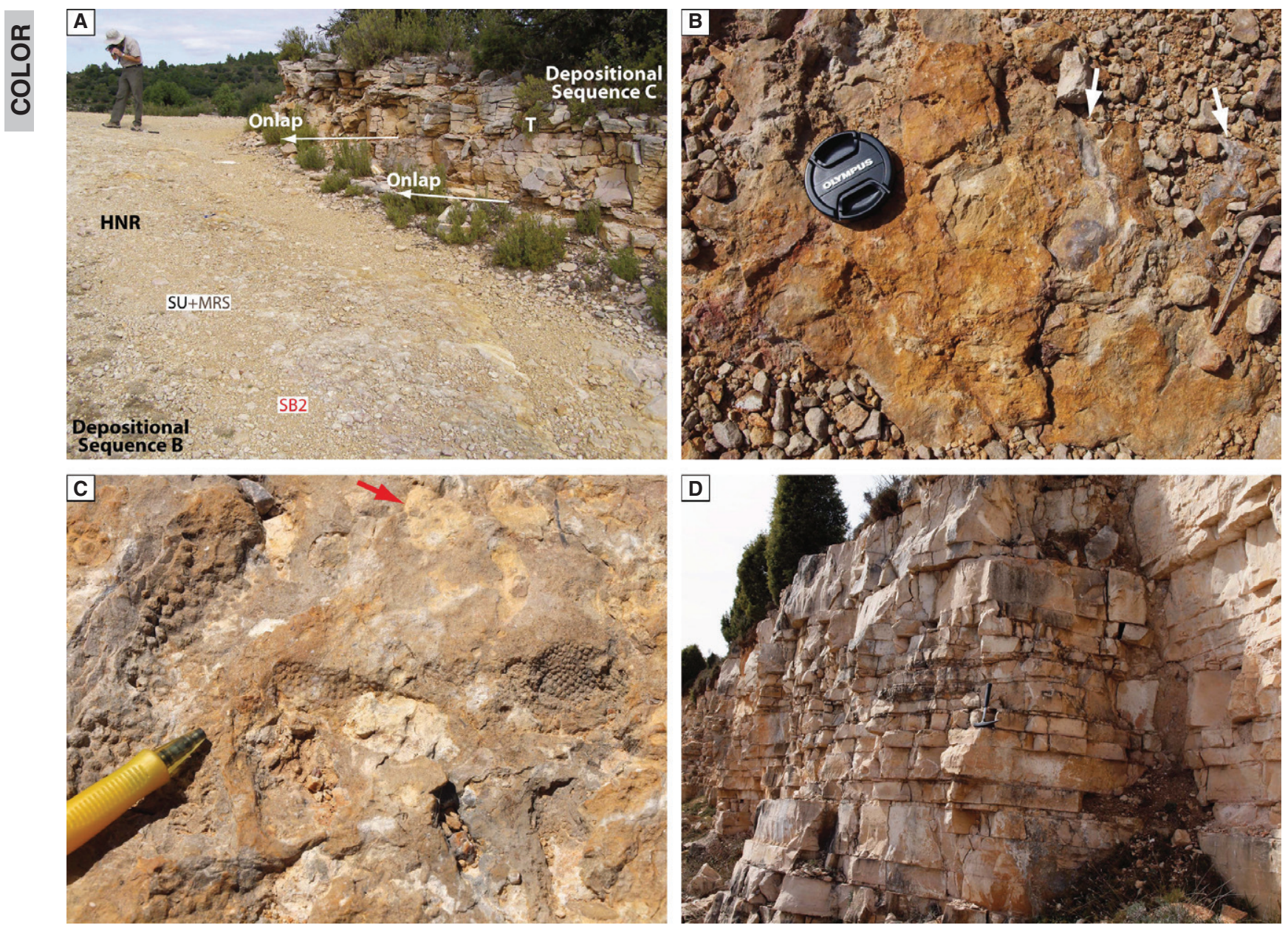

Fig. 17. Sequence Boundary 2 and dolomitized peritidal deposits of the Mola de la Saranyana. (A) Outcrop-scale view of the upper part of the preserved transgressive deposits of Depositional Sequence C banked against the incised highstand platform carbonates of Depositional Sequence B. South-western face of the Mola d'en Camaràs. See Fig. 3 for key. Geologist at upper left for scale is ca $1.8 \mathrm{~m}$ tall. (B) Detail of the Sequence Boundary 2 displayed in (A). Note the iron staining exhibited by the surface. White arrows point to encrusting oyster shells, which are associated with marine onlap after subaerial exposure and thus, indicate the superposition of a maximum regressive surface onto the subaerial unconformity. Camera cap $=5.8 \mathrm{~cm}$. (C) Close-up view of the Sequence Boundary 2 shown in (A). Note the truncated external coral moulds and whitish and yellowish infillings (red arrow) exhibited by this composite surface. Visible part of pen $=5.7 \mathrm{~cm}$. (D) Outcrop view of the well-bedded peritidal dolostones. Mola de la Saranyana. Hammer length $=32 \mathrm{~cm}$.

\section{Depositional Sequence B}

Lowstand normal regressive genetic type of deposit

After the onset of subsequent base-level rise, accommodation increased and a lowstand normal regressive carbonate platform developed. This platform onlaps slopes of the highstand platform of Depositional Sequence A and downlaps onto the correlative conformity; either over basin marls (Figs 3B, 9C and 10C) or over forced regressive units (Figs 3B, 8, 11B and 13C). The lowstand deposits are $c a 10 \mathrm{~m}$ thick, belong to the Villarroya de los Pinares Formation and are formed by the platform lithofacies, which pass basinwards to slope lithofacies (Figs 3B, 13B, C and $14 \mathrm{~A}, \mathrm{~B})$. The corresponding lowstand basin lithofacies are not preserved due to present-day erosion.

The lowstand platform displays prograding clinoforms towards the north (Fig. 14A and B) and channel-fill geometries, which drain northwards as well (Fig. 13B and C). Characteristic fauna of the lowstand platform identified are Praeorbitolina, Mesorbitolina lotzei, Nautiloculina bronnimanni, and requieniid, polyconitid and caprinid (Fig. 12B) rudists. The presence of 


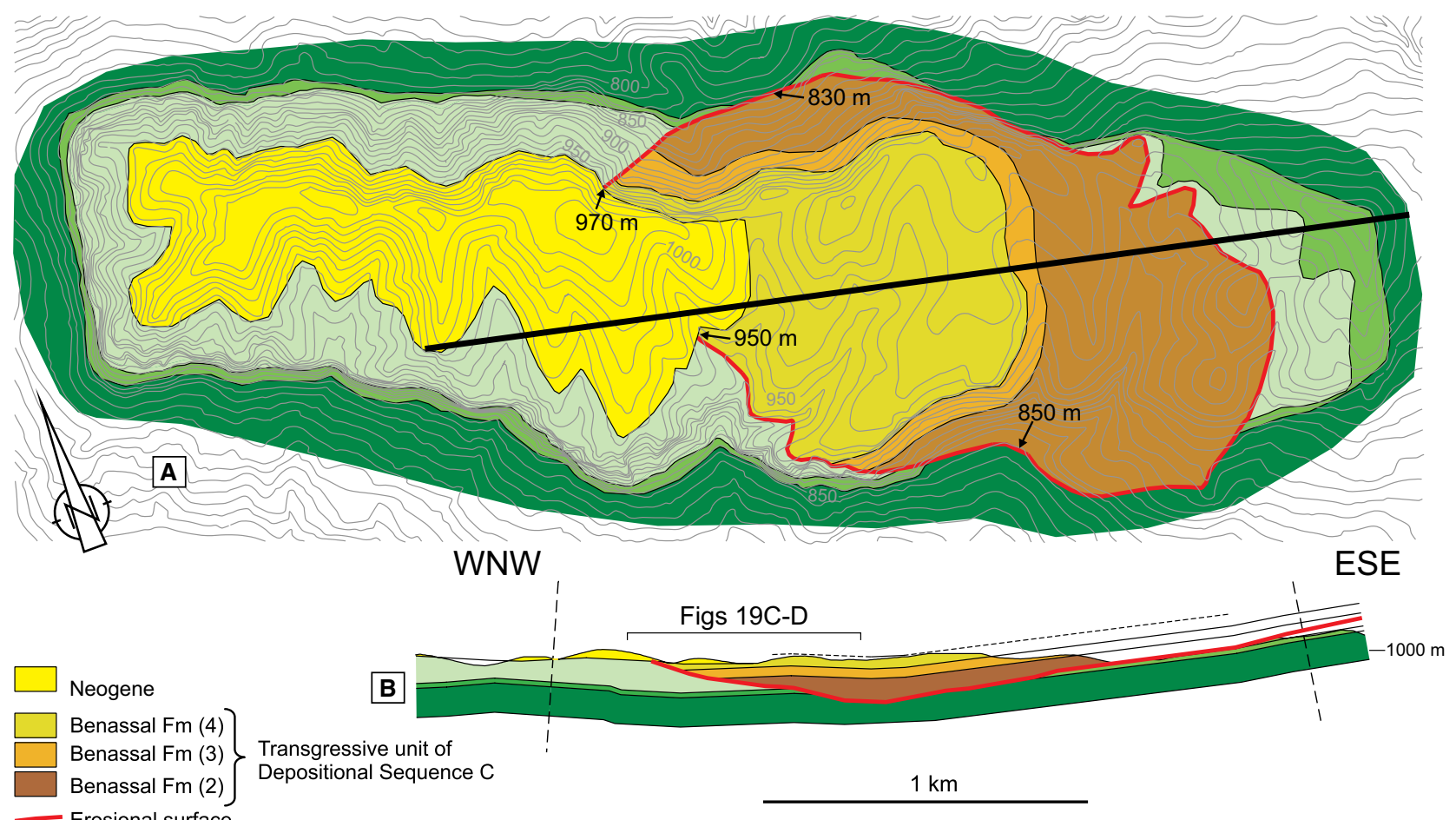

- Erosional surface

Benassal Fm (1) - Transgressive and highstand normal regressive units of Depositional Sequence B

Villarroya de los Pinares Fm - Lowstand normal regressive unit of Depositional Sequence B

$\square$ Forcall Fm - Transgressive unit

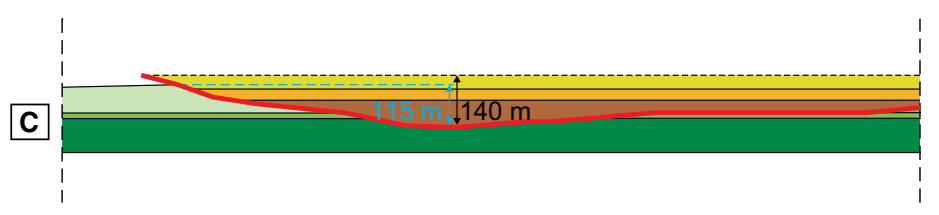
of Depositional Sequence A

Fig. 18. Incision characterization. (A) Geological map of the Mola d'en Camaràs with the situation of the erosional surface. Elevation contours (grey lines) and the present maximum and minimum elevations of the incision on the NE and SW slopes are shown (black figures). The contour line interval is $10 \mathrm{~m}$. The black line marks the geological cross-section reconstructed in (B) and (C). See Figs 1C and 4 for location of the Mola d'en Camaràs. (B) Geological cross-section of the seismic-scale incision present at the Mola d'en Camaràs. The outcrop expression of the area marked with the segment is displayed in Fig. 19C and D. (C) Restoration to the pre-contractional stage (prior to the Alpine deformation) of the geological cross-section shown in (B). Note the kilometric-scale dimension (width) of the incision and the stepped nature (strath terraces) of the sides. The depth of the incised valley from the top of the highstand carbonates of Depositional Sequence B preserved to the bottom is $115 \mathrm{~m}$. Assuming that the uppermost transgressive deposits of Depositional Sequence C preserved were sedimented within the incision, its maximum depth would then be $140 \mathrm{~m}$.

Praeorbitolina, Mesorbitolina lotzei and Caprinidae indicates an Early Aptian age (Schroeder et al., 2010; Cherchi \& Schroeder, 2012; Skelton \& Gili, 2012).

\section{Transgressive genetic type of deposit}

With the end of the stage of normal regression and the onset of transgression, the lowstand platform was drowned and buried by transgressive marl deposits that correspond to the basin lithofacies association (Figs 3C, 8, 10C, and 14A, B). A well-developed hardground with widespread $\mathrm{Fe}-\mathrm{Mn}$ crusts, encrusting oysters (Fig. 14C) and borings of lithophagid bivalves marks the drowning of the platform. This drowning surface corresponds to a maximum regressive surface, which is observed as both smooth and irregular. In some parts of the Mola de la Garumba, a transgressive lag (Fig. 14D), preserved as a packstone containing abundant fragments of decapods and gastropods, fills the depressions occasionally exhibited by this surface.

The basal part of the transgressive marl interval, which corresponds to the lower part of the Benassal Formation (Fig. 2), is characterized by the presence of Dufrenoyia dufrenoyi specimens (Fig. 12C to E). Therefore, the basal part of these 

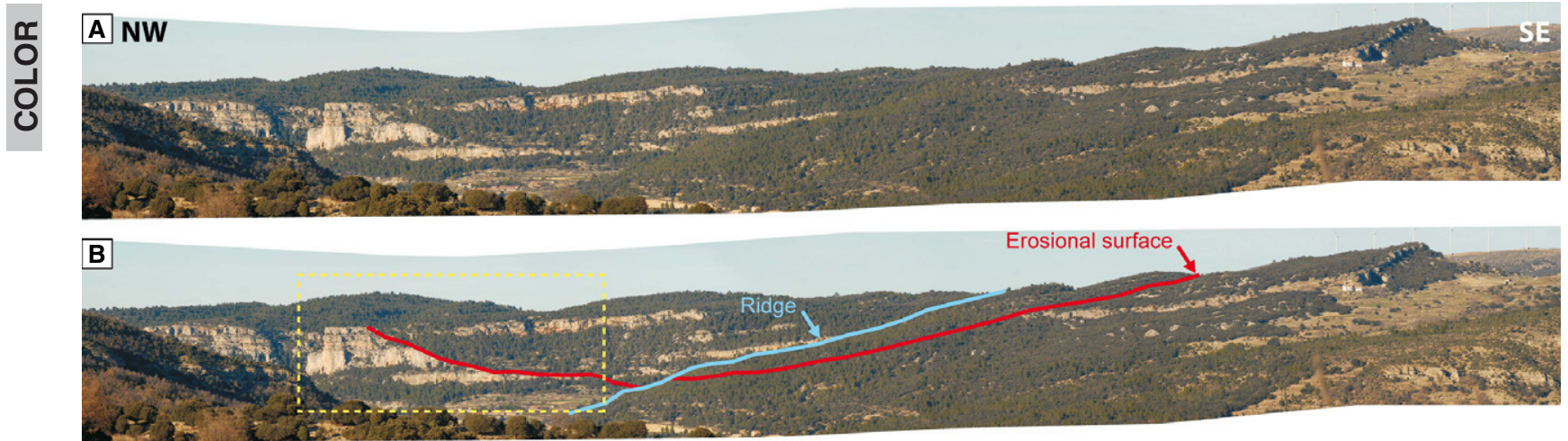

C

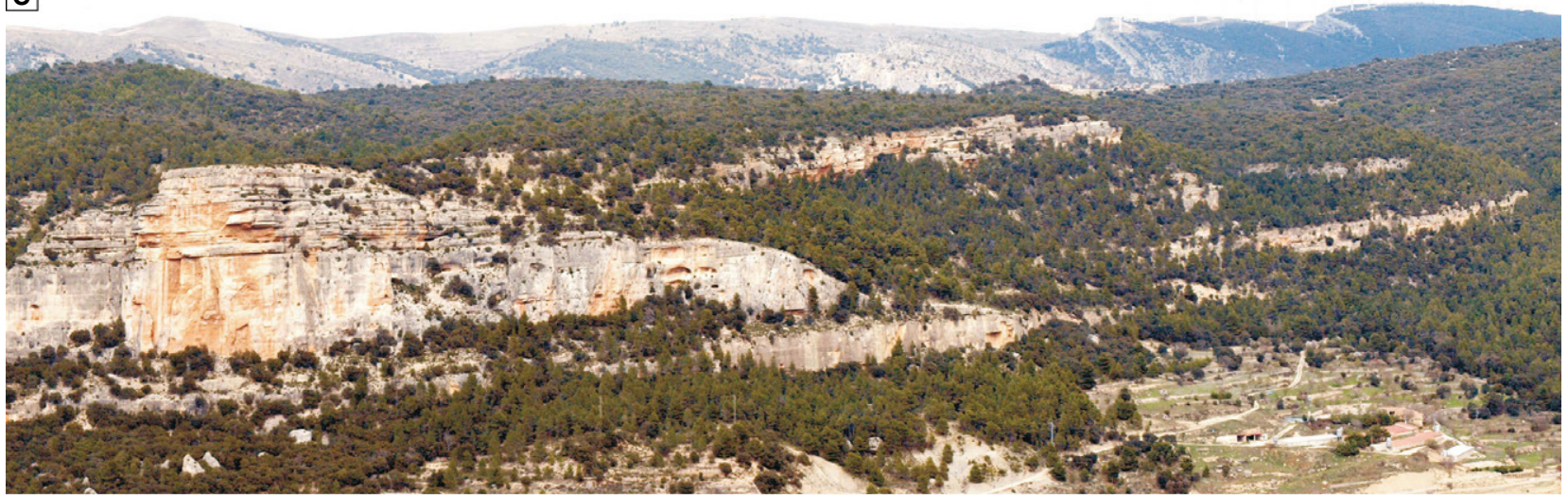

D

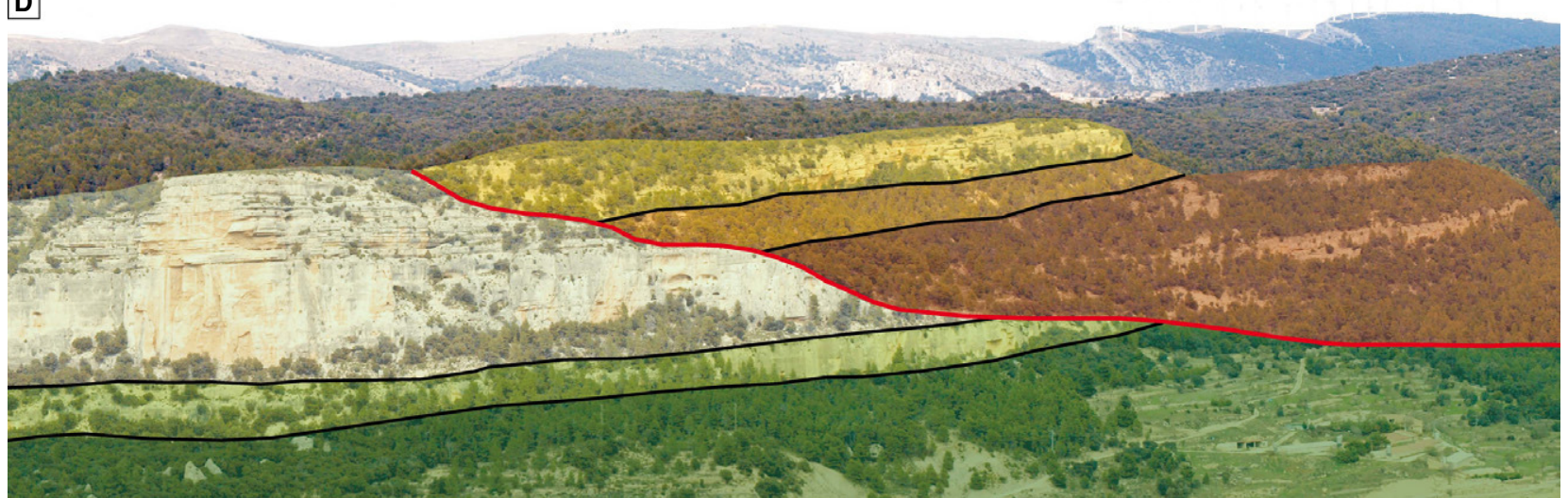

Fig. 19. Incision characterization. (A) Panoramic view of the south-western face of the Mola d'en Camaràs showing the Late Aptian incised valley documented. This photomosaic corresponds to the outcrop expression of Fig. 18B. See Figs 1C and 4 for location of the Mola d'en Camaràs. Width of image is ca $2 \cdot 9 \mathrm{~km}$. (B) Interpretation of (A). The area outlined in yellow is enlarged in (C) and (D). (C) Outcrop expression of the area indicated with a segment in the geological cross-section displayed in Fig. 18B. (D) Interpretation of (C). See Fig. 18 for key.

transgressive deposits is Early Aptian in age (Figs 2, 3D and 8). Another common organism identified in the marls is Panopea sp.

\section{Highstand normal regressive genetic type of deposit}

With the onset of regression, a large carbonate platform (Figs 3C, 8, 10 and 15) developed (Benassal Formation). The lower part of this carbonate system is distinguished by beds composed of the slope lithofacies association (Fig. 8). The corresponding basin lithofacies is not preserved. The maximum flooding surface of the sequence is interpreted following the same criterion used for the maximum flooding surface of Depositional Sequence A; at the limit between the transgressive marls and the downlapping slopes of the highstand normal 
regressive platform (Figs 3C, 8, 10C and 15C). The lower platform-top carbonates (platform lithofacies association) are massive and thick, while the upper deposits are characterized by thinner beds (Figs 10 and 15) arranged in parasequences of up to few metres thick, reflecting a loss in accommodation as a consequence of the slowing of the relative sea-level rise to a near standstill.

Fossils identified at species level are Orbitolinopsis simplex (Fig. 12F), Mesorbitolina texana (Fig. 12G), Everticyclammina hedbergi and Charentia cuvilieri. The presence of Mesorbitolina texana and of Orbitolinopsis simplex indicates a Late Aptian age (Schroeder et al., 2010; Cherchi \& Schroeder, 2012). Given that the first appearance of Mesorbitolina texana occurs at the base of the highstand platform, the boundary between the Early and the Late Aptian may be located within the transgressive marls, somewhere above the basal level with Dufrenoyia furcata ammonites (Figs 2, 3D and 8).

\section{Forced regression}

The subsequent relative sea-level fall subaerially exposed the platform of Depositional Sequence B (Figs 3D, 15 and 16). The resulting subaerial unconformity corresponds to Sequence Boundary 2 (Fig. 17A to C). This surface limits depositional sequences $\mathrm{B}$ and $\mathrm{C}$, but also $\mathrm{C}$ and $\mathrm{A}$ at the Mola d'en Camaràs where the Aptian succession was locally incised as a result of base-level fall (Fig. 7). Consequently, Depositional Sequence B was locally eroded (Figs 3D, 7, 15 and 16). The subaerial unconformity exhibits a stepped morphology (Figs 15 and 16) and locally, truncated external moulds of massive and branching colonial corals (Fig. 17C). The voids left by the dissolution of the aragonite coral skeletons are partially to completely filled with whitish, yellowish and brownish finegrained material (Fig. 17C). Given that the most basinward part of the highstand platform of Depositional Sequence B is not preserved (Figs 1C, 4, 7, 10, 13A and 15A), forced regressive deposits cannot be recognized.

The incision documented (Figs 15 and 16) is a unique feature and has not been recognized at the other hillocks within the study area (Fig. 1). However, at the Mola de la Saranyana (Figs 1C and 4) a metre-sized sedimentary succession of tabular-bedded completely dolomitized peritidal deposits with very limited lateral extent (few tens of metres) (Fig. 17D) crops out above transgressive basinal marls of Depositional Sequence
B. Such proximal lithofacies could be relics of the peritidal infill of an incised valley. However, highstand deposits of Depositional Sequence B are not preserved in this hillock (Fig. 7). Therefore, it is not possible to confirm that the Mola de la Saranyana was incised during the Late Aptian forced regressive stage of Depositional Sequence B.

\section{Depositional Sequence C}

\section{Lowstand normal regression}

At the lowest point of relative sea-level and with the succeeding relative sea-level rise, available depositional space shifted basinwards. Normal regressive deposits may have accumulated in these distal settings, while the proximal areas of the highstand platform of Depositional Sequence B stayed emerged. However, the most distal parts of this carbonate platform are not preserved (Figs 1C, 4, 7, 10, $13 \mathrm{~A}$ and $15 \mathrm{~A}$ ).

Transgressive genetic type of deposit

Coinciding with transgression, a maximum regressive surface characterized by a hardground, was superposed onto the subaerial unconformity corresponding to Sequence Boundary 2, and thus, a composite surface formed (Figs 3D, 9, 15, 16 and 17A to C). Hardground features displayed by the maximum regressive surface are borings of lithophagid bivalves, iron stains and encrusting oysters (Fig. 17B). The incision was back-filled with transgressive deposits (Benassal Formation), which onlap Sequence Boundary 2 (Figs 3D, 9, 15 and 16). Biota identified at genus level in the transgressive rocks are Praeorbitolina sp. and Choffatella sp. The incision cuts the Aptian succession from the highstand carbonates of Depositional Sequence B down to the transgressive marls of Depositional Sequence A (Figs 3D, 9C, 15C and 16B). The uppermost part of the incision back-fill (Figs 9, 15, 16 and $17 \mathrm{~A}$ ) is characterized by cross-stratified grainstones with herring-bone cross-bedding (Fig. 6D) and tidal bundles (Fig. 6E). Where these high-energy deposits onlap the transgressive marls of Depositional Sequence B, the subaerial unconformity would have been eroded and the sequence boundary would then correspond to a transgressive ravinement surface. Fluvial or coarse-grained siliciclastic deposits back-filling the incision were not observed. 


\section{INCISION CHARACTERIZATION}

The seismic-scale erosional incision located at the Mola d'en Camaràs (Figs 1,4 and 18A) is characterized with a geological map and a cross-section (Fig. 18B). In its present state, the difference in elevation between the lowest and the highest part of the incision is $100 \mathrm{~m}$ on the SW slope (950 to $850 \mathrm{~m}$ ) and $140 \mathrm{~m}$ on the NE slope (970 to $830 \mathrm{~m}$ ) (Figs $18 \mathrm{~A}$ and $\mathrm{B}$ ). The cross-section was restored to the pre-contractional geometry (prior to the Alpine orogeny) (Fig. 18C) to define the original shape and dimensions of the incision. The restored cross-section displays a preserved portion of the incision that is $c a 2 \mathrm{~km}$ wide, with clear down-cutting of $115 \mathrm{~m}$ into the Aptian succession. This difference in elevation was obtained by means of a linear interpolation between the heights measured for the two aforementioned slopes. However, if the uppermost transgressive deposits of Depositional Sequence C preserved were deposited within the incision, the depth of the incision would then be $140 \mathrm{~m}$ (Fig. 18C). The upper part of the transgressive unit and the original lateral extent of the subaerial unconformity are not preserved due to Neogene and present-day erosion (Figs 18A, B and 19). Therefore, the original incision probably would have been larger in both width $(>2 \mathrm{~km})$ and depth $(>140 \mathrm{~m})$.

The shape and dimensions of the depression indicate the incision was a valley (Fig. 18C), which had a south-west to north-east trend (Fig. 18). The north-western and south-eastern sides of the palaeovalley exhibit a stepped geometry (Figs 9C, 15B, C, 16B, 18B, C and 19).

\section{DISCUSSION}

\section{Genesis of the palaeovalley}

A submarine origin for the seismic-scale incision discovered in the northern Maestrat Basin has been ruled out. Tidal currents are not effective in eroding competent strata such as limestone bedrock (Mitchell et al., 2013). In addition, oceanic streams capable of scouring bedrock are normally generated in the basin seaward from the carbonate shelves (Pinet et al., 1981; Pinet \& Popenoe, 1985). Moreover, the channels produced by these oceanic currents do not exhibit stepped sides or peritidal infills (Pinet \& Popenoe, 1985), and are therefore not comparable with the Late Aptian valley under study (Figs 6, 15, 18 and 19).

On the other hand, the palaeovalley was incised owing to base-level fall. The stepped geometry exhibited by its sides indicates that the incision originated under subaerial conditions as a result of alternating periods of streamcutting erosion and lateral planation (Figs 15, 16, and 19C, D). The steps correspond to strath terraces given that the palaeovalley is incised in bedrock. Moreover, valleys incised across exposed continental shelves are commonly back-filled by fluvial and/or peritidal deposits (e.g. Dalrymple et al., 1992; Zaitlin et al., 1994; Nouidar \& Chellaï, 2001; Ardies et al., 2002; Chaumillon et al., 2008; Raven et al., 2010) as observed in the incision studied (Fig. 6).

The morphology of the palaeovalley, but not the depth, could have been accentuated by wave abrasion during the transgressive stage of Depositional Sequence C. However, it is highly unlikely that the stepped sides correspond to wave-cut benches given that both sides of the incision show this geometric feature (Figs 15, 16, and 19C, D).

\section{Sequential development of the sedimentary succession}

In this study, four genetic types of deposits separated by key sequence stratigraphic surfaces were recognized: forced regressive, lowstand normal regressive, transgressive and highstand normal regressive (Fig. 3). Results provide a valuable example of the four genetic unit-based sequence stratigraphic method for interpreting marine carbonate successions, which is useful for academic and industrial applications.

However, the application of sequence stratigraphy to the interpretation of incision back-fill deposits is often problematic. Within the valley, due to spatial limitation and confinement, the geometric arrangement of the sedimentary fill does not provide any evidence of deposition during a specific stage of relative sea-level (Figs 15, 16, 17 A and 19). Examples of transgressive valley-fill successions are numerous in the literature (e.g. Dalrymple et al., 1992; Ardies et al., 2002; Zaitlin et al., 2002; Chaumillon et al., 2008; Raven et al., 2010). However, the possibility that the lowermost and uppermost strata of the incision back-fill could also correspond to lowstand and highstand normal regressive deposits, respectively, should not be discarded. Although the infill succession 
exhibits the shallowest lithofacies association reported in the study, in order to accumulate $\geq 115 \mathrm{~m}$ thick peritidal to shallow subtidal carbonates (Fig. 18C), rapid creation of accommodation is needed. This need is typical of

2 transgressive sequences. The shift from subaerially exposed stream-cut bedrock to peritidal back-fill deposits is also indicative of marine onlap. Therefore, the incised valley is interpreted as having been filled during the transgressive stage of Depositional Sequence C (Figs 2, 3, 15 and 16).

In addition, multiple superimposed cycles of incision and sedimentation were not observed within the sedimentary fill. Therefore, following the classification by Zaitlin et al. (1994), the incised valley-fill succession corresponds to a simple fill, i.e. a single depositional sequence.

\section{Age control of depositional sequences}

Using the absolute ages of Gradstein et al. (2004), the duration of Depositional Sequence A, which contains all of the Early Aptian ammonoid zones (Fig. 2), would be between $3 \mathrm{Myr}$ and $4 \mathrm{Myr}$. The base of Depositional Sequence B, which corresponds to the basal part of the Benassal Formation, correlates to the uppermost Dufrenoyia furcata Zone of Early Aptian age (Moreno-Bedmar et al., 2012a; Figs 2, 8 and $12 \mathrm{C}$ to E). Therefore, the limit between the Early and Late Aptian would be located within the transgressive marls of Depositional Sequence B (Figs 2, 3 and 8). The upper boundary of this sequence and the sedimentary fill of Depositional Sequence C lack precise biostratigraphic control. However, these deposits cannot be of Albian age because the Escucha Formation, which regionally unconformably overlies the Benassal Formation, contains the first Albian ammonoid Zone (Garcia et al., 2014). The Escucha Formation is not preserved in the study area, but is present overlying the Benassal Formation a few kilometres to the north, in the environs of the village of Herbers (Querol et al., 1992), still within the Morella Sub-basin. In addition, the occurrence of Toucasia sp. and Polyconites sp. rudist shells in life position at the upper part of the sedimentary back-fill succession also rules out a Late Cretaceous or Cenozoic age (Masse, 1995) for these rocks, and hence the possibility that the formation of the incised valley studied could have been related to the Alpine orogeny (Late Eocene-Early Miocene;
Salas et al., 2001). Therefore, given that the Late Aptian spanned 9 Myr (Gradstein et al., 2004), Depositional Sequence B together with the transgressive phase of Depositional Sequence C, would have had a duration of $<9$ Myr.

The transgressive back-fill deposits of Depositional Sequence C contain Praeorbitolina specimens, indicating an Early Aptian age (Schroeder et al., 2010; Cherchi \& Schroeder, 2012). However, Mesorbitolina texana (Fig. 12G) and Orbitolinopsis simplex (Fig. 12F), which are indicative of the Late Aptian (Schroeder et al., 2010; Cherchi \& Schroeder, 2012), are found in the incised highstand platform carbonates of Depositional Sequence B. The incised highstand platform of Depositional Sequence B cannot be younger than its back-fill. Therefore, the Praeorbitolina specimens present in the transgressive peritidal deposits of Depositional Sequence C were reworked during transgression into the Late Aptian back-fill.

\section{Duration and magnitude of the long-term changes in accommodation}

The late Early Aptian forced regressive stage recognized occurred within the Dufrenoyia furcata ammonite biozone (Fig. 2), which according to Gradstein et al. (2004) spanned $1 \mathrm{Myr}$. The Dufrenoyia furcata Biozone is contemporaneous with sedimentation of the uppermost transgressive and the highstand deposits of Depositional Sequence A, and to the lowstand and basal transgressive stages of Depositional Sequence B (Fig. 2). Therefore, given the time constraints, this fall of relative sea-level would have had a duration of less than $1 \mathrm{Myr}$.

The amplitude of relative sea-level change during the late Early Aptian forced regression can also be roughly estimated. The preserved highstand platform carbonates of Depositional Sequence A (Fig. 11A) are $c a 80 \mathrm{~m}$ thick, whereas the lowstand platform of Depositional Sequence B (Figs 10, 13, 14A, B, 15 and 16), which is situated in a basinward position with respect to the highstand platform (Fig. 3), locally overlying forced regressive wedges (Figs 3, 8, $11 \mathrm{~B}$ and 13), is only $c a 10 \mathrm{~m}$ thick. Both platforms exhibit the same lithofacies distribution (Figs 3 and 12A and B) and thus, are interpreted as having developed at similar depths. To accommodate a $10 \mathrm{~m}$ thick lowstand carbonate succession at the toe of the slope of a highstand platform (Fig. 3), which originally was $\geq 80 \mathrm{~m}$ 
thick, a relative sea-level drop of at least tens of metres is needed.

The forced regressive stage of Depositional Sequence B is of Late Aptian age (Fig. 2). Other than the occurrence of Dufrenoyia dufrenoyi specimens within the basal transgressive deposits of this depositional sequence (Figs 8 and 12C to E), no ammonites have been identified and so an approximate estimation of the duration of the relative sea-level fall cannot be made. Depositional Sequence B and the transgressive stage of Depositional Sequence C occurred in $<9$ Myr. Thus, the Late Aptian forced regressive phase would have had a duration of much less than 9 Myr.

The incised valley characterized permits an accurate determination of the amplitude of this drop in relative sea-level that was at least $115 \mathrm{~m}$, but may have been $>140 \mathrm{~m}$ (Fig. 18C). Given that the incision was completely backfilled by peritidal to shallow subtidal deposits during the subsequent transgression (Figs 3, 6, 15,16 and 19), the magnitude of the following relative sea-level rise within Depositional Sequence C would also have been $\geq 115 \mathrm{~m}$ (Fig. 18C).

The depth at which the transgressive marls of Depositional Sequences A and B were deposited is unknown, making it difficult to accurately estimate the amplitude of these transgressions. However, the transgressive deposits of Depositional Sequence A (Forcall Formation) contain the entire Deshayesites forbesi and Deshayesites deshayesi ammonoid biozones, the lower part of the Dufrenoyia furcata Zone and at least the upper part of the Deshayesites oglanlensis Zone (Fig. 2; Moreno-Bedmar et al., 2010; Garcia et al., 2014). Therefore, according to the absolute ages of Gradstein et al. (2004), this transgression would have spanned between $2 \mathrm{Myr}$ and 4 Myr.

The basal transgressive unit of Depositional Sequence B (Benassal Formation) recorded the uppermost part of the Dufrenoyia furcata Zone (Figs 2, 8 and $12 \mathrm{C}$ to E). The rest of the transgressive marls of Depositional Sequence B were thus most probably deposited during the earliest Late Aptian (Figs 2, 3 and 8). Age-diagnostic ammonites of Late Aptian age were not found in the outcrops studied. Therefore, a more exact estimation of the duration of the transgressive stage of Depostional Sequence B is not possible to construe. However, according to the absolute ages provided in Gradstein et al. (2004), it would have been much less than $9 \mathrm{Myr}$, given that the Late Aptian substage would have spanned 9 Myr.

\section{Regional significance of the long-term changes in accommodation}

The transgressive unit of Depositional Sequence A (Figs 2 and 3), which corresponds to the marls with ammonites of the Forcall Formation (Figs 5C and 10), is observed throughout the Maestrat Basin (Fig. 1A and B) with similar lithofacies and a thickness ranging from tens to hundreds of metres (Salas, 1987; Salas et al., 2001; Vennin \& Aurell, 2001; Moreno-Bedmar et al., 2009, 2010; Bover-Arnal et al., 2010, 2011a,b; Embry et al., 2010; Garcia et al., 2014). Thickness variations are related to differential accommodation due to pronounced compartmentalization into fault blocks of the basin during the Early Aptian (Salas et al., 2001; Bover-Arnal et al., 2010; Moreno-Bedmar et al., 2010; Martín-Martín et al., 2013).

The late Early Aptian (intra Dufrenoyia furcata Zone) forced regression of Depositional Sequence A (Figs 2 and 3) has been also recognized in the central Galve Sub-basin in the western Maestrat Basin (Fig. 1B; Bover-Arnal et al., 2009, 2010, 2011a). There, as in the Morella Sub-basin, the occurrence of platform-detached wedges deposited above the basinal marls of the Forcall Formation, and topographically below a highstand platform, provides evidence of baselevel fall during the late Early Aptian (BoverArnal et al., 2009, 2011a). In the central Galve Sub-basin, the rate of this relative sea-level drop was at least $60 \mathrm{~m}$ in $<1 \mathrm{Myr}$ (Bover-Arnal et al., 2009). Further, palaeokarst features located at the top of the preserved highstand carbonates of Depositional Sequence A and a kilometre-wide late Early Aptian incision down-cutting the sedimentary succession to tens of metres deep (Peropadre et al., 2007; Bover-Arnal et al., 2009, 2010, 2011a) are preserved in the Galve Subbasin. This erosional surface also displays strath terraces (fig. 10 in Bover-Arnal et al., 2011a), as observed in this study.

The transgressive stage of Depositional Sequence B (Fig. 3), which was coeval with deposition of the marly unit of the lower part of the Benassal Formation (Figs 2, 8, and 14A, B), can also be traced throughout the Maestrat Basin (Salas, 1987; Salas et al., 2001; Vennin \& Aurell, 2001; Bover-Arnal et al., 2009, 2010, 2011a; Embry et al., 2010; Moreno-Bedmar et al., 2010, 2012a; Martín-Martín et al., 2013; Garcia et al., 
2014). Similar to the Morella Sub-basin, in the central Galve Sub-basin (Fig. 1B), this transgression leads to drowning of the lowstand carbonate platform during the latest Early Aptian (Bover-Arnal et al., 2009). In the central Galve Sub-basin, backstepping carbonates associated with this transgressive episode have been observed (Bover-Arnal et al., 2009).

Evidence for a pronounced regression during the Late Aptian is also found in other sub-basins of the Maestrat Basin such as Galve, Penyagolosa and La Salzedella (Fig. 1B). In these sub-basins, Late Aptian highstand platform carbonates with the same rudists and coral assemblages of the Benassal Formation, shallow upwards to a thick unit (up to hundreds of metres) of very shallow marine to transitional deposits composed of ferruginous ooid grainstones, sandstones, sandy limestones and clays (Salas, 1987; Bover-Arnal et al., 2010). To date, incised valleys such as the one characterized in this study (Figs 2, 3, 15, 16, 18 and 19) have not been identified in the latter sub-basins. During the Late Aptian, these sub-basin grabens recorded an interval of rapid syn-rift subsidence (Salas et al., 2001; Bover-Arnal et al., 2010; Martín-Martín et al., 2013), which may have counterbalanced base-level fall. However, enhanced sediment supply of siliciclastic sediments matched subsidence, resulting in an overall regression (Bover-Arnal et al., 2010).

In summary, the long-term trends of relative sea-level recognized in the Morella Sub-basin (northern Maestrat Basin) are observed to have regional significance. However, each of the subbasins within the Maestrat Basin would have had particular sedimentary expression in response to local tectonics.

\section{Global significance of the long-term changes in accommodation}

The global Aptian sedimentary record is calibrated with biostratigraphic data (e.g. MorenoBedmar et al., 2009, 2010, 2012a,b; Schroeder et al., 2010; Cherchi \& Schroeder, 2012) and/or analyses of stable isotopes such as C or Sr (e.g. Burla et al., 2008, 2009; Huck et al., 2011, 2012). However, the duration of changes in depositional trends recognized in the stratigraphic record is less than the resolution of these calibration methods, which can have errors of up to millions of years. Therefore, relative ages that are used to calibrate Aptian strata cannot be used as absolute age correlations between stratigraphic units and/or changes in accommodation recorded in different basins. Consequently, the synchronicity of Aptian sedimentary events is always difficult to test. Despite those limitations, when reviewing the literature, there striking similarities exist between the changes in depositional trends, lithofacies evolution and geometric relation of sedimentary successions characterized in this study and those reported from rocks of the same age from different basins worldwide.

In this regard, deposition of the Early Aptian transgressive marls of Depositional Sequence A (Forcall Formation; Figs 2, 3, and 10B, C) coincide with a large-scale transgression that has been recorded along the margin of the Tethys (e.g. Föllmi et al., 1994; Sahagian et al., 1996; Hardenbol et al., 1998; Wissler et al., 2003; Husinec \& Jelaska, 2006). This Early Aptian transgression was accompanied by mass occurrences of orbitolinids in the Tethyan neritic realm (Vilas et al., 1995; Pittet et al., 2002; Burla et al., 2008; Bover-Arnal et al., 2010; Embry et al., 2010; Stein et al., 2012).

The late Early Aptian fall in relative sea-level of Depositional Sequence A (Figs 2 and 3) also has potential counterparts elsewhere in the Tethys (Haq et al., 1988; Hardenbol et al., 1998). Arnaud \& Arnaud-Vanneau (1989) reported the existence of a late Early Aptian subaerial unconformity associated with incised valleys of several hundred metres wide, which down-cut platform carbonates in south-eastern France. Subaerial exposure surfaces above platform carbonates of late Early Aptian age have been also recognized in the Lusitanian Basin in Portugal (Burla et al., 2008), in the Basque-Cantabrian Basin in northern Spain (Rosales, 1999; García-Mondéjar et al., 2009; Fernández-Mendiola et al., 2013), in the Organyà Basin in the Catalonian Pre-Pyrenees (Bernaus et al., 2003), in the Adriatic platform in Croatia (Husinec \& Jelaska, 2006), in Oman (van Buchem et al., 2010; Rameil et al., 2012), in onshore Abu Dhabi in the United Arab Emirates (Yose et al., 2010), in the Levant Basin in southern Lebanon and northern Egypt (Bachmann \& Hirsch, 2006), in the Apennines in Italy (Ruberti et al., 2013) and in the western Taurides in Turkey (Yilmaz \& Altiner, 2006). In addition, late Early Aptian regressive deposits have been identified in the north-western Pacific guyots (Röhl \& Ogg, 1998) and in south-eastern Ethiopia (Bosellini et al., 1999).

Transgressive deposits correlative with the transgressive phase of Depositional Sequence B 
(Figs 2 and 3), have also been reported in other basins of the Tethys and the Atlantic extension of it (Haq et al., 1988; Hardenbol et al., 1998). Latest Early Aptian drowning of carbonate platforms occurred in Mexico (Moreno-Bedmar et al., 2012a), Venezuela (Jacquin et al., 1993) and south-eastern France (Masse \& FenerciMasse, 2013). Wilmsen et al. (2013) also placed the time of the drowning of the Shah Kuh Platform in Central Iran near the boundary between the Early and the Late Aptian. Similarly, Röhl \& Ogg (1998) identified a transgressive phase in the western Pacific guyots that began in the uppermost Early Aptian.

Evidence of a pronounced Late Aptian relative sea-level drop potentially coeval to the forced regressive stage of Depositional Sequence B (Figs 2 and 3), is also widespread (Haq et al., 1988; Hardenbol et al., 1998). Deposits equivalent to this regressive stage are the Upper Aptian lowstand clinoforms on the Arabian Plate (Morrison et al., 1997; Maurer et al., 2010; Pierson et al., 2010). These are interpreted as the lowstand of the Late Aptian to early Albian Supersequence (van Buchem et al., 2010). Incised valleys of that age have been described from: the Arabian Plate (Raven et al., 2010; Maurer et al., 2013), where incisions are up to $65 \mathrm{~m}$ deep and $8 \mathrm{~km}$ wide and infilled by estuarine deposits; western Siberia (Medvedev et al., 2011), where incised valleys are up to $90 \mathrm{~m}$ deep and also infilled with estuarine materials; and in western Canada (Zaitlin et al., 2002), where incisions of up to $40 \mathrm{~m}$ deep are infilled with siliciclastic tidalites. The transgressive infill of Depositional Sequence C is of latest Aptian age, such as the siliciclastic backfills observed in Qatar (Raven et al., 2010) and western Siberia (Medvedev et al., 2011). In addition, Late Aptian sea-level falls of up to tens of metres in magnitude have been recognized in Venezuela (Jacquin et al., 1993), the western Pacific guyots (Röhl \& Ogg, 1998), the Adriatic Platform in Croatia (Husinec \& Jelaska, 2006), the North Sea (Crittenden et al., 1997), Yemen (Morrison et al., 1997) and the Russian Platform (Sahagian et al., 1996; Zorian \& Ruban, 2012). Palaeogeographic maps showing the location of sites with evidence of significant relative sea-level falls of Aptian age are found in Rameil et al. (2012) and Maurer et al. (2013).

In summary, long-term changes in relative sealevel that are observed in the northern Maestrat Basin have also been described in numerous Aptian successions worldwide. Similar sedimentary expressions of these relative sealevel changes such as a comparable lithofacies evolution, drowning of carbonate platforms during the latest Early Aptian or the occurrence of deeply incised valleys during the Late Aptian can be recognized in distinct tectonic plates. Therefore, all these different examples seem to indicate that a global mechanism is responsible for controlling base level during the Aptian in the Morella Sub-basin.

\section{On the triggering mechanism of the long-term changes in accommodation}

Long-term relative sea-level fluctuations $(0.5$ to $6 \mathrm{Myr}$ ) such as the ones recognized in the northern Maestrat Basin are commonly interpreted as having a tectonic and/or climatic origin (e.g. Vail et al., 1977, 1991; Cloetingh, 1986, 1991; Boulila et al., 2011). The main mechanisms for changes in accomodation are: glacio-eustasy, tectono-eustasy and thermo-eustasy (global); and sediment supply, uplift, and thermal and tectonic subsidence (regional) (e.g. Cronin, 1999; Immenhauser, 2005). These mechanisms can act in concert or in isolation. Consequently, reconstructing the relative contribution of each of these factors is a challenge.

Falls in relative sea-level of tens of metres in $<1$ Myr or of $\geq 115 \mathrm{~m}$ in much less than $9 \mathrm{Myr}$, such as are recognized in the northern Maestrat Basin (Figs 2 and 3), are considered 'rapid' in geological terms (e.g. Cronin, 1999; Immenhauser \& Matthews, 2004; Gréselle \& Pittet, 2005; Miller et al., 2005a). Along the same lines, the incised valley documented was completely filled within the Aptian Stage. Therefore, the rate of the latest Late Aptian transgressive phase of Depositional Sequence C (Figs 2, 3, 15, 16, 18 and 19) would have been similar to one of the Late Aptian forced regression of Depositional Sequence B. According to Immenhauser (2005), the only known mechanisms of sea-level fluctuations that would produce rates of change matching the above are regional tectonism, glacio-eustasy and ocean-volume changes.

Changes in the volume of the ocean basins are commonly related to volcanic activity at the mid-oceanic ridges and to subduction of one continent beneath another (e.g. Kominz, 2001). However, neither intense magmatic activity at oceanic ridges, nor subduction processes can explain the rates of sea-level change documented. Thermal anomalies causing rapid spreading of oceanic ridges would be expected 
to trigger rapid transgressions and much slower forced regressive phases (Immenhauser, 2005), which is the opposite phenomenon to that observed in the northern Maestrat Basin (Fig. 2). Rates of sea-level change due to plate subduction differ by at least one order of magnitude from those estimated in the Morella Sub-basin and so cannot account for the sea-level falls recognized. As an example, the subduction of the Indian Plate under the Eurasian Plate has generated a sea-level drop of $c a 70 \mathrm{~m}$ during the last 50 Myr (Kominz, 2001).

During the Aptian, the northern Maestrat Basin was bound by a major normal fault with a west-east trend (Herbers fault). Due to hangingwall accommodation, the depocentre of the Morella Sub-basin, and thus the basinward direction of the depositional system studied, was towards the north-west and north-east (Fig. 1B). This trend is demonstrated in the platform top to slope clinoforms that prograde NW$\mathrm{NE}$ in the lowstand and highstand platforms of Depositional Sequence B (Figs 13B, C and 14A, $\mathrm{B})$; this supports fault-induced subsidence as a factor in creating accommodation.

The southern area of the Morella Sub-basin, where the carbonate succession studied crops out (Fig. 1B), corresponds to the upthrown part of the tilted fault block and thus, to proximal settings of the depositional system. Therefore, tectonic uplift linked to the tilting of the fault block could have accounted, at least partially, for the long-term late Early and Late Aptian forced regressions identified.

However, the nature, amplitude and duration of the relative sea-level falls documented cannot be explained solely as the result of regional tectonic processes. Coeval drops of tens of metres in relative sea-level have been recognized worldwide (e.g. Hardenbol et al., 1998; Bover-Arnal et al., 2009; Maurer et al., 2010, 2013; Husinec et al., 2012; Rameil et al., 2012), so there must be a eustatic component. In addition, Immenhauser (2005) estimated rates of $c a \quad 0.65$ to $0.88 \mathrm{~m} \mathrm{Myr}^{-1}$ for Jurassic and Cretaceous sea-level changes associated with regional to plate-scale tectonism. These estimated rates are considerably lower than the changes of tens of metres in $<1 \mathrm{Myr}$ or of $\geq 115 \mathrm{~m}$ in $<9 \mathrm{Myr}$ observed. Therefore, the most plausible mechanism capable of producing such rapid fluctuations in sea-level is glacio-eustasy (Matthews \& Frohlich, 2002; Immenhauser, 2005; Miller et al., 2005a,b) and inherent steric (thermal) effects (e.g. Cronin, 1999). In support of this interpretation, a $\geq 115 \mathrm{~m}$ change (Fig. 18C), is in accordance with glacio-eustatic controls (e.g. Immenhauser, 2005; Miller et al., 2005a,b). Sea-level variations recorded during glacial cycles frequently exceed $100 \mathrm{~m}$ in amplitude (e.g. Church \& Gregory, 2001). For example, during the last glacial maximum ( $c a 21 \mathrm{ka}$ ), sealevel was $c a 120 \mathrm{~m}$ below the current level (e.g. Fleming et al., 1998; Peltier, 2002).

Literature reporting or supporting the existence of late Early and/or Late Aptian cooling phases is abundant (e.g. Krassilov, 1973; Pickton, 1981; Kemper, 1987; Frakes \& Francis, 1988, 1990; Weissert \& Lini, 1991; Ditchfield et al., 1994; Stoll \& Schrag, 1996; Abreu et al., 1998; Clarke \& Jenkyns, 1999; De Lurio \& Frakes, 1999; Ferguson et al., 1999; Hochuli et al., 1999; Price, 1999; Alley \& Frakes, 2003; Herrle \& Mutterlose, 2003; Pucéat et al., 2003; Steuber et al., 2005; Rückheim et al., 2006; Cather et al., 2009; Mutterlose et al., 2009; Amiot et al., 2011; Skelton \& Gili, 2012). The data presented in the latter studies come from late Early and Late Aptian intervals in basins located in a variety of different latitudes and longitudes, indicating a global significance. Given that the timing of these cooling phases fits well with the late Early and Late Aptian periods of reduced accommodation recognized in several basins worldwide, a glacio-eustatic mechanism is commonly favoured (e.g. Gréselle \& Pittet, 2005; Bover-Arnal et al., 2009; van Buchem et al., 2010; Maurer et al., 2010, 2013; Raven et al., 2010; Husinec et al., 2012; Rameil et al., 2012).

Evidence of pronounced cooling during the late Early and Late Aptian is also found within the Maestrat Basin. Terrestrial palynological studies by Solé de Porta \& Salas (1994) provide evidence of a late Early to Late Aptian climate more arid and colder than that of the earliest part of the Early Aptian and the subsequent Albian Stage, which were characterized by warmer and more humid environmental conditions. These results are based on an observed significant rise in bisaccate pollen abundance in late Early and Late Aptian stratigraphic intervals. Recently, Cors et al. (2013) have identified a late Early Aptian cooling event that affected the vegetation of the hinterland in the western Maestrat Basin. Here, a marked decrease in Classopollis gymnosperm pollen paralleled by increasing abundances of Araucariacites pollen is interpreted as reflecting a shift towards cooler and probably less arid climatic conditions. This trend has been recognized within the marls of 
the Forcall Formation and is most pronounced in post-Early Aptian Oceanic Anoxic Event strata (Bover-Arnal et al., 2011b). In summary, the Aptian sedimentary succession of the Maestrat Basin provides evidence of late Early and Late Aptian cooling trends that precede or are coeval with stratal geometric relations and sedimentary features that resulted from base-level fall.

\section{CONCLUSIONS}

Although the amplitude and duration of the two relative sea-level falls reported are within the glacio-eustatic domain (respectively, of tens of metres in $<1 \mathrm{Myr}$ and of $\geq 115 \mathrm{~m}$ in $<9 \mathrm{Myr}$ ), results do not unambiguously prove that the growth and melting of large continental ice-sheets was the main process controlling long-term accommodation changes in the northern Maestrat

3 Basin during the Aptian. However, the relative sea-level trends recognized, and their sedimentary expression (for example, the presence of a Late Aptian incised valley with a peritidal to shallow subtidal back-fill), are comparable to those documented in coeval sedimentary successions from other basins worldwide, and thus have an important eustatic component. If these eustatic variations in sea-level are taken in context with the existing bibliography of sedimentological, mineralogical, palaeontological and geochemical studies reporting the occurrence of cooling events in the Aptian, glacio-eustasy becomes a plausible mechanism for explaining these sea-level changes identified.

Finally, the wider importance of the study lies in the documentation and interpretation of the outcrops analysed in the northern Maestrat Basin. These rock exposures allow investigation of the stratal architecture and lithofacies relations of global long-term relative sea-level fluctuations of Aptian age at the outcrop scale, where they are often only recognizable at much larger (seismic) scales.

\section{ACKNOWLEDGEMENTS}

We are very grateful to Danielle Thomson for reviewing an early version of the manuscript, making many useful suggestions and improving the English. We would like to thank Frans S.P. van Buchem for fruitful discussions in the field. Felix Schlagintweit, Peter W. Skelton, Annie
Arnaud-Vanneau and Josep Maria Bernaus are greatly thanked for determining several fossil specimens. Ulrich Heimhofer provided valuable information on the pollen record from the western Maestrat Basin. Helpful reviews by Florian Maurer, Karl Föllmi, Gregor Eberli, Linda Pickett and Tracy Frank are gratefully acknowledged. Funding was provided by the Swiss National Science Foundation grant no. 20-137568, the I+D+i research project: CGL2008-04916, the Consolider-Ingenio 2010 programme, under CSD 2006-0004 'Topo-Iberia', and the Grup Consolidat de Recerca 'Geologia Sedimentària' (2009SGR-1451).

\section{REFERENCES}

Abreu, V.S., Hardenbol, J., Haddad, G.A., Baum, G.R., Droxler, A.W. and Vail, P.R. (1998) Oxygen isotope synthesis: a Cretaceous ice-house? In: Mesozoic and Cenozoic Sequence Stratigraphy of European Basins (Eds P.C. de Gracianski, J. Hardenbol, T. Jacquin and P.R. Vail), SEPM Spec. Publ., 60, 75-80.

Alley, N.F. and Frakes, L.A. (2003) First known Cretaceous glaciation: Livingston Tillite Member of the Cadna-owie Formation, South Australia. Aust. J. Earth Sci., 50, 139-144.

Amiot, R., Wang, X., Zhou, Z., Wang, X., Buffetaut, E., Lécuyer, C., Ding, Z., Fluteau, F., Hibino, T., Kusuhashi, N., Mo, J., Suteethorn, V., Wang, Y., Xu, X. and Zhang, F. (2011) Oxygen isotopes of East Asian dinosaurs reveal exceptionally cold Early Cretaceous climates. Proc. Natl Acad. Sci., 108, 5179-5183.

Ardies, G.W., Dalrymple, R.W. and Zaitlin, B.A. (2002) Controls on the geometry of incised valleys in the Basal Quartz Unit (Lower Cretaceous), Western Canada Sedimentary Basin. J. Sed. Res., 72, 602-618.

Arnaud, H. and Arnaud-Vanneau, A. (1989) Sequences de depot et variations du niveau relatif de la mer au Barremien et a l'Aptien inferieur dans les massifs subalpins septentrionaux et le Jura (sud-est de la France). Bull. Soc. Géol. Fr., 5, 651-660.

Bachmann, M. and Hirsch, F. (2006) Lower Cretaceous carbonate platform of the eastern Levant (Galilee and the Golan Heights): stratigraphy and second-order sea-level change. Cretaceous Res., 27, 487-512.

Bernaus, J.M., Arnaud-Vanneau, A. and Caus, E. (2003) Carbonate platform sequence stratigraphy in a rapidly subsiding area: the Late Barremian-Early Aptian of the Organyà basin, Spanish Pyrenees. Sed. Geol., 159, 177-201

Bosellini, A., Russo, A. and Schroeder, R. (1999) Stratigraphic evidence for an Early Aptian sea-level fluctuation: the Graua Limestone of south-eastern Ethiopia. Cretaceous Res., 20, 783-791.

Boulila, S., Galburn, B., Miller, K.G., Pekar, S.F., Browning, J.V., Laskar, J. and Wright, J.D. (2011) On the origin of Cenozoic and Mesozoic "third-order" eustatic sequences. Earth Sci. Rev., 109, 94-112.

Bover-Arnal, T., Salas, R., Moreno-Bedmar, J.A. and Bitzer, K. (2009) Sequence stratigraphy and architecture of a late 
Early-Middle Aptian carbonate platform succession from the western Maestrat Basin (Iberian Chain, Spain). Sed. Geol., 219, 280-301.

Bover-Arnal, T., Moreno-Bedmar, J.A., Salas, R., Skelton, P.W., Bitzer, K. and Gili, E. (2010) Sedimentary evolution of an Aptian syn-rift carbonate system (Maestrat Basin, E Spain): effects of accommodation and environmental change. Geol. Acta, 8, 249-280.

Bover-Arnal, T., Salas, R., Skelton, P.W., Gili, E. and Moreno-Bedmar, J.A. (2011a) The Aptian carbonate platforms of the western Maestrat Basin: a textbook example of four systems tract-based sequence stratigraphy. In: Pre-Meeting Field Trips Guidebook, 28th IAS Meeting, Zaragoza (Eds C. Arenas, L. Pomar and F. Colombo), Sociedad Geológica de España, Geo-Guías, 7, 27-64.

Bover-Arnal, T., Salas, R., Martín-Closas, C., Schlagintweit, F. and Moreno-Bedmar, J.A. (2011b) Expression of an oceanic anoxic event in a neritic setting: lower Aptian coral rubble deposits from the western Maestrat Basin (Iberian Chain, Spain). Palaios, 26, 18-32.

Bover-Arnal, T., Löser, H., Moreno-Bedmar, J.A., Salas, R. and Strasser, A. (2012) Corals on the slope (Aptian, Maestrat Basin, Spain). Cretaceous Res., 37, 43-64.

van Buchem, F.S.P., Al-Husseini, M.I., Maurer, F., Droste, H.J. and Yose, L.A. (2010) Sequence-stratigraphic synthesis of the Barremian - Aptian of the eastern Arabian Plate and implications for the petroleum habitat. In: Barremian - Aptian Stratigraphy and Hydrocarbon Habitat of the Eastern Arabian Plate (Eds F.S.P. van Buchem, M.I. Al-Husseini, F. Maurer and H.J. Droste), GeoArabia Spec. Publ. 4, Gulf PetroLink, Bahrain, 1, 9-48.

Burla, S., Heimhofer, U., Hochuli, P.A., Weissert, H. and Skelton, P. (2008) Changes in sedimentary patterns of coastal and deep-sea successions from the North Atlantic (Portugal) linked to Early Cretaceous environmental change. Palaeogeogr. Palaeoclimatol. Palaeoecol., 257, 38-57.

Burla, S., Oberli, F., Heimhofer, U., Wiechert, U. and Weissert, H. (2009) Improved time control on Cretaceous coastal deposits: new results from $\mathrm{Sr}$ isotope measurements using laser ablation. Terra Nova, 21, 401-409.

Canérot, J., Cugny, P., Pardo, G., Salas, R. and Villena, J. (1982) Ibérica Central-Maestrazgo. In: El Cretácico de España(Ed. A. García), pp. 273-344. Universidad

4 Complutense de Madrid, ???.

Cather, S.M., Dunbar, N.W., McDowell, F.W., McIntosh, W.C. and Scholle, P.A. (2009) Climate forcing by iron fertilization from repeated ignimbrite eruptions: the icehouse-silicic large igneous province (SLIP) hypothesis. Geosphere, 5, 315-324.

Catuneanu, O., Abreu, V., Bhattacharya, J.P., Blum, M.D., Dalrymple, R.W., Eriksson, P.G., Fielding, C.R., Fisher, W.L., Galloway, W.E., Gibling, M.R., Giles, K.A., Holbrook, J.M., Jordan, R., Kendall, C.G., St, C., Macurda, B., Martinsen, O.J., Miall, A.D., Neal, J.E., Nummedal, D., Pomar, L., Posamentier, H.W., Pratt, B.R., Sarg, J.F., Shanley, K.W., Steel, R.J., Strasser, A., Tucker, M.E. and Winker, C. (2009) Towards the standardization of sequence stratigraphy. Earth Sci. Rev., 92, 1-33.

Catuneanu, O., Galloway, W.E., Kendall, C.G.St.C., Miall, A.D., Posamentier, H.W., Strasser, A. and Tucker, M.E. (2011) Sequence stratigraphy: methodology and nomenclature. Newsl. Stratigr., 443, 173-245.

Chakraborty, P.P. and Paul, S. (2008) Forced regressive wedges on a Neoproterozoic siliciclastic shelf:
Chandarpur Group, central India. Precambrian Res., 162, 227-247.

Chaumillon, E., Proust, J.-N., Menier, D. and Weber, N. (2008) Incised-valley morphologies and sedimentary-fills within the inner shelf of the Bay of Biscay (France): a synthesis. J. Mar. Syst., 72, 383-396.

Cherchi, A. and Schroeder, R. (2012) The Praeorbitolina/ Palorbitolinoides Association: an Aptian biostratigraphic key-interval at the southern margin of the Neo-Tethys. Cretaceous Res., 39, 70-77.

Church, J.A. and Gregory, J.M. (2001) Sea level change. In: Encyclopedia of Ocean Sciences (Eds J.H. Steele, K.K. Turekian and S.A. Thorpe), pp. 2599-2604. Academic Press, ???.

Clarke, L.J. and Jenkyns, H.C. (1999) New oxygen isotope evidence for long-term Cretaceous climate change in the Southern Hemisphere. Geology, 27, 699-702.

Cloetingh, S. (1986) Intraplate stresses: a new tectonic mechanism for fluctuations of relative sea level. Geology, 14, 617-620.

Cloetingh, S. (1991) Tectonics and sea-level changes: a controversy? Ice age interludes during the time of Cretaceous greenhouse climate? In: Controversies in Modern Geology: Evolution of Geological Theories in Sedimentology, Earth History and Tectonics (Eds D.W. Müller, J.A. McKenzie and H. Weissert), pp. 249-277. Academic Press, ???.

Cors, J., Heimhofer, U., Bover-Arnal, T. and Salas, R. (2013) Spore-pollen assemblage records delayed terrestrial cooling in response to organic carbon burial during OAE1a. Geophys. Res. Abstracts, 15, EGU2013-1898.

Crittenden, S., Cole, J.M. and Kirk, M.J. (1997) The distribution of Aptian sand-stones in the central and northern North Sea (UK sectors): a lowstand systems tract "play". Part 1: stratigraphy, biostratigraphic age determination, and genesis of the sandstones. J. Petrol. Geol., 20, 3-25.

Cronin, T.M. (1999) Principles of Paleoclimatology. Columbia University Press, New York, p. 560.

Dalrymple, R.W., Zaitlin, B.A. and Boyd, R. (1992) Estuarine facies models: conceptual basis and stratigraphic implications. J. Sed. Petrol., 62, 1130-1146.

De Lurio, J.L. and Frakes, L.A. (1999) Glendonites as a paleoenvironmental tool: implications for early Cretaceous high latitude climates in Australia. Geochim. Cosmochim. Acta, 63, 1039-1048.

Ditchfield, P.W., Marshall, J.D. and Pirrie, D. (1994) High latitude palaeotemperature variation: new data from the Tithonian to Eocene of James Ross Island, Antarctica. Palaeogeogr. Palaeoclimatol. Palaeoecol., 107, 79-101.

Dunham, R.J. (1962) Classification of carbonate rocks according to depositional texture. In: Classification of Carbonate Rocks (Ed. W.E. Ham), Am. Assoc. Petrol. Geol. Mem., 1, 108-121.

Embry, A.F. and Klovan, J.E. (1971) A Late Devonian reef tract on northeastern Banks Island, N.W.T. Bull. Can. Petrol. Geol., 19, 730-781.

Embry, J.-C., Vennin, E., Van Buchem, F.S.P., Schroeder, R., Pierre, C. and Aurell, M. (2010) Sequence stratigraphy and carbon isotope stratigraphy of an Aptian mixed carbonate-siliciclastic platform to basin transition (Galve sub-basin, NE Spain). Geol. Soc. London Spec. Publ., 329, 113-143.

Ferguson, K.M., Gregory, R.T. and Constantine, A. (1999) Lower Cretaceous (Aptian-Albian) secular changes in the 
oxygen and carbon isotope record from high paleolatitude, fluvial sediments, southeast Australia: Comparisons to the marine record. In: Evolution of the Cretaceous OceanClimate System (Eds E. Barrera and C.C. Johnson), Geol. Soc. Am. Spec. Paper, 332, 59-72.

Fernández-Mendiola, P.A., Mendicoa, J., Hernandez, S., Owen, H.G. and García-Mondéjar, J. (2013) A facies model for an Early Aptian carbonate platform (Zamaia, Spain). Facies, 59, 529-558.

Fleming, K., Johnston, P., Zwartz, D., Yokoyama, Y., Lambeck, K. and Chappell, J. (1998) Refining the eustatic sea-level curve since the Last Glacial Maximum using farand intermediate-field sites. Earth Planet. Sci. Lett., 163, 327-342.

Föllmi, K.B., Weissert, H., Bisping, M. and Funk, H. (1994) Phosphogenesis, carbon-isotope stratigraphy, and carbonate-platform evolution along the Lower Cretaceous northern Tethyan margin. Geol. Soc. Am. Bull., 106, 729-746.

Frakes, L.A. and Francis, J.E. (1988) A guide to Phanerozoic cold polar climates from high-latitude ice-rafting in the Cretaceous. Nature, 333, 547-549.

Frakes, L.A. and Francis, J.E. (1990) Cretaceous palaeoclimates. In: Cretaceous Resources, Events, and Rhythms (Eds R.N. Ginsburg and B. Beaudoin), pp.

7 287-373. Kluwer Academic Publishers, ???.

Garcia, R., Moreno-Bedmar, J.A., Bover-Arnal, T., Company, M., Salas, R., Latil, J.L., Martín-Martín, J.D., Gomez-Rivas, E., Bulot, L.G., Delanoy, G., Martínez, R. and Grauges, A. (2014) Lower Cretaceous (HauterivianAlbian) ammonite biostratigraphy in the Maestrat Basin ( $\mathrm{E}$

8 Spain). J. Iberian Geol., ???, ???-???.

García-Mondéjar, J., Owen, H.G., Raisossadat, N., Millán, M.I. and Fernández-Mendiola, P.A. (2009) The early Aptian of Aralar (northern Spain): stratigraphy, sedimentology, ammonite biozonation, and OAE1a. Cretaceous Res., 30, 434-464.

Gradstein, F.M., Ogg, J.G. and Smith, A.G. (2004) A Geologic Time Scale 2004. Cambridge University Press, Cambridge, p. 610.

Gréselle, B. and Pittet, B. (2005) Fringing carbonate platforms at the Arabian Plate margin in northern Oman during the Late Aptian-Middle Albian: evidence for highamplitude sea-level changes. Sed. Geol., 175, 367-390.

Guimerà, J. (1984) Palaeogene evolution of deformation in the northeastern Iberian Peninsula. Geol. Mag., 121, 413420.

Haq, B.U., Hardenbol, J. and Vail, P.R. (1988) Mesozoic and Cenozoic chronostratigraphy and cycles of sea-level change. In: Sea-Level Changes - An Integrated Approach (Eds C.K. Wilgus, C.A. Ross and H. Posamentier), SEPM Spec. Publ., 42, 71-108.

Hardenbol, J., Thierry, J., Farley, M.B., Jacquin, T., de Gracianski, P.C. and Vail, P.R. (1998) Mesozoic and Cenozoic Sequence Chronostratigraphic Framework of European Basins. In: Mesozoic and Cenozoic Sequence Stratigraphy of European Basins (Eds P.C. de Gracianski, J. Hardenbol, T. Jacquin and P.R. Vail), SEPM Spec. Publ., 960 , ???-???, charts 1-8.

Hay, W.W. (2008) Evolving ideas about the Cretaceous climate and ocean circulation. Cretaceous Res., 29, 725-753.

Hay, W.W. (2011) Can humans force a return to a 'Cretaceous' climate? Sed. Geol., 235, 5-26.

Herrle, J.O. and Mutterlose, J. (2003) Calcareous nannofossils from the Aptian-Lower Albian of southeast
France: palaeoecological and biostratigraphic implications. Cretaceous Res., 24, 1-22.

Hillgärtner, H. (1998) Discontinuity surfaces on a shallowmarine carbonate platform (Berriasian, Valanginian, France and Switzerland). J. Sed. Res., 68, 1093-1108.

Hillgärtner, H., Van Buchem, F.S.P., Gaumet, F., Razin, P., Pittet, B., Grötsch, J. and Droste, H. (2003) The BarremianAptian evolution of the eastern Arabian carbonate platform margin (northern Oman). J. Sed. Res., 73, 756-773.

Hochuli, P.A., Menegatti, A.P., Weissert, H., Riva, A., Erba, E. and Premoli Silva, I. (1999) Episodes of high productivity and cooling in the early Aptian Alpine Tethys. Geology, 27, 657-660.

Huck, S., Heimhofer, U., Rameil, N., Bodin, S. and Immenhauser, A. (2011) Strontium and carbon-isotope chronostratigraphy of Barremian-Aptian shoal-water carbonates: Northern Tethyan platform drowning predates OAE 1a. Earth Planet. Sci. Lett., 304, 547-558.

Huck, S., Heimhofer, U. and Immenhauser, A. (2012) Early Aptian algal bloom in a neritic proto-North Atlantic setting: Harbinger of global change related to OAE 1a? Geol. Soc. Am. Bull., 124, 1819-1825.

Hunt, D. and Tucker, M.E. (1992) Stranded parasequences and the forced regressive wedge systems tract: deposition during base-level fall. Sed. Geol., 81, 1-9.

Husinec, A. and Jelaska, V. (2006) Relative sea-level changes recorded on an isolated carbonate platform: Tithonian to Cenomanian succession, Southern Croatia. J. Sed. Res., 76, 1120-1136.

Husinec, A., Harman, C.A., Regan, S.P., Mosher, D.A., Sweeney, R.J. and Read, J.F. (2012) Sequence development influenced by intermittent cooling events in the Cretaceous Aptian greenhouse, Adriatic platform, Croatia. AAPG Bull., 96, 2215-2244.

Immenhauser, A. (2005) High-rate sea-level change during the Mesozoic: new approaches to an old problem. Sed. Geol., 175, 277-296.

Immenhauser, A. and Matthews, R.K. (2004) Albian sealevel cycles from Oman: the 'Rosetta Stone' approach. GeoArabia, 9, 11-46.

Immenhauser, A., Schlager, W., Burns, S.J., Scott, R.W., Geel, T., Lehmann, J., van der Gaast, S. and BolderSchrijver, L.J.A. (1999) Late Aptian to Late Albian sealevel fluctuations constrained by geochemical and biological evidence (Nahr Umr Formation, Oman). J. Sed. Res., 69, 434-446.

Jacquin, T., Azpiritxaga, I., Murat, B. and Roberto, M.F. (1993) Sequential evolution of Lower Cretaceous carbonate platforms in the Maracaibo Basin, Venezuela. Am. Assoc. Petrol. Geol. Bull., 77, 326.

Kemper, E. (1987) Das Klima der Kreidezeit. Geol. Jb. Reihe A, 96, 399.

Kominz, M.A. (2001) Sea Level Variations Over Geologic Time. In: Encyclopedia of Ocean Sciences (Eds J.H. Steele, K.K. Turekian and S.A. Thorpe), pp. 2605-2613. Academic Press, Oxford.

Krassilov, V.A. (1973) Climatic changes in Eastern Asia as indicated by fossil floras I. Early Cretaceous. Palaeogeogr. Palaeoclimatol. Palaeoecol., 13, 261-273.

Martín, L., Leyva, F. and Canérot, J. (1972) Morella, Hoja $n^{o}$ 545. Mapa Geológico de España 1:50.000. $2^{\mathrm{a}}$ Serie. $1^{\mathrm{a}}$ Edición. Servicio de Publicaciones, Ministerio de Industria y Energía, Madrid.

Martín-Martín, J.D., Gomez-Rivas, E., Bover-Arnal, T., Travé, A., Salas, R., Moreno-Bedmar, J.A., Tomás, S., 
Corbella, M., Teixell, A., Vergés, J. and Stafford, S.L. (2013) The Upper Aptian to Lower Albian synrift carbonate succession of the southern Maestrat Basin (Spain): facies architecture and fault-controlled stratabound dolostones. Cretaceous Res., 41, 217-236.

Masse, J.-P. (1995) Lower Cretaceous rudist biostratigraphy of southern France - a reference for Mesogean correlations. Rev. Mex. Cienc. Geol., 12, 236-256.

Masse, J.-P. and Fenerci-Masse, M. (2013) Stratigraphic updating and correlation of Late Barremiane-Early Aptian Urgonian successions and their marly cover, in their type region (Orgon-Apt, SE France). Cretaceous Res., 39, 17-38.

Matthews, R.K. and Frohlich, C. (2002) Maximum flooding surfaces and sequence boundaries: comparisons between observations and orbital forcing in the Cretaceous and Jurassic (65-190 Ma). GeoArabia, 7, 503-538.

Maurer, F., Al-Mehsin, K., Pierson, B.J., Eberli, G.P., Warrlich, G., Drysdale, D. and Droste, H.J. (2010) Facies characteristics and architecture of Upper Aptian Shu'aiba clinoforms in Abu Dhabi. In: Barremian - Aptian Stratigraphy and Hydrocarbon Habitat of the Eastern Arabian Plate (Eds F.S.P. van Buchem, M.I. Al-Husseini, F. Maurer and H.J. Droste), GeoArabia Spec. Publ. 4, Gulf 10 PetroLink, Bahrain, 2, 445-468.

Maurer, F., van Buchem, F.S.P., Eberli, G.P., Pierson, B.J., Raven, M.J., Larsen, P.-H., Al-Husseini, M.I. and Benoit, V. (2013) Late Aptian long-lived glacio-eustatic lowstand recorded on the Arabian Plate. Terra Nova, 25, 87-94.

Medvedev, A.L., Lopatin, A.Y. and Masalkin, Y.V. (2011) Comparative characteristics of the lithological composition of the incised valley fill and host sediments of the Vikulovo Formation, Kamenny Area, West Siberia. Lithol. Mineral Resour., 46, 369-381.

Miller, K.G., Kominz, M.A., Browning, J.V., Wright, J.D., Mountain, G.S., Katz, M.E., Sugarman, P.J., Cramer, B.S., Christie-Blick, N. and Pekar, S.F. (2005a) The phanerozoic record of global sea-level change. Science, 310, 1293-1298.

Miller, K.G., Wright, J.D. and Browning, J.V. (2005b) Visions of ice sheets in a greenhouse world. Mar. Geol., 217, 215-231.

Mitchell, N.C., Huthnance, J.M., Schmitt, T. and Todd, B. (2013) Threshold of erosion of submarine bedrock landscapes by tidal currents. Earth Surf. Proc. Land., 38, 627-639.

Moreno-Bedmar, J.A., Company, M., Bover-Arnal, T., Salas, R., Delanoy, G., Martínez, R. and Grauges, A. (2009) Biostratigraphic characterization by means of ammonoids of the lower Aptian Oceanic Anoxic Event (OAE1a) in the eastern Iberian Chain (Maestrat Basin, eastern Spain). Cretaceous Res., 30, 864-872.

Moreno-Bedmar, J.A., Company, M., Bover-Arnal, T., Salas, R., Maurrasse, F.J., Delanoy, G., Grauges, A. and Martínez, R. (2010) Lower Aptian ammonite biostratigraphy in the Maestrat Basin (Eastern Iberian Chain, Eastern Spain). A Tethyan transgressive record enhanced by synrift subsidence. Geol. Acta, 8, 281-299.

Moreno-Bedmar, J.A., Bover-Arnal, T., Barragán, R. and Salas, R. (2012a) Uppermost Lower Aptian transgressive records in Mexico and Spain: chronostratigraphic implications for the Tethyan sequences. Terra Nova, 24, 333-338.

Moreno-Bedmar, J.A., Company, M., Sandoval, J., Tavera, J.M., Bover-Arnal, T., Salas, R., Delanoy, G., Maurrasse, F.J.-M.R. and Martínez, R. (2012b) Lower Aptian ammonite and carbon isotope stratigraphy in the eastern Prebetic Domain (Betic Cordillera, southeastern Spain). Geol. Acta, 10, 333-354.

Morrison, J., Birse, A., Samuel, M.A., Richardson, S.M., Harbury, N. and Bott, W.F. (1997) The Cretaceous sequence stratigraphy of the Socotran Platform, the Republic of Yemen. Mar. Petrol. Geol., 14, 685-699.

Mutterlose, J., Bornemann, A. and Herrle, J.O. (2009) The Aptian-Albian cold snap: evidence for 'mid' Cretaceous icehouse interludes. Neues Jb. Geol. Paläontol. Abh., 252, $217-225$

Navarro-Vázquez, D., Crespo-Zamorano, A., Pérez-Castaño, A. and Canérot, J. (1972) Forcall, Hoja $n^{\circ}$ 544. Mapa Geológico de España 1:50.000. $2^{\text {a }}$ Serie. $1^{\text {a }}$ Edición. Servicio de Publicaciones, Ministerio de Industria y Energía, Madrid.

Nouidar, M. and Chellaï, E.H. (2001) Facies and sequence stratigraphy of an estuarine incised-valley fill: lower Aptian Bouzergoun Formation, Agadir Basin, Morocco. Cretaceous Res., 22, 93-104.

Peltier, W.R. (2002) On eustatic sea level history: last glacial maximum to Holocene. Quatern. Sci. Rev., 21, 377-396.

Peropadre, C., Meléndez, N. and Liesa, C.L. (2007) A 60 metres Aptian sea-level fall from the Galve sub-basin (Eastern Spain). 25th IAS Meeting of Sedimentology, abstract vol., Patras, Greece, September 2007, p. 27.

Pickton, C.A.G. (1981) Palaeogene and Cretaceous dropstones in Spitsbergen. In: Earth's Prepleistocene Glacial Record (Eds M.J. Hambrey and W.B. Harland), pp. 567-569. Cambridge University Press, Cambridge.

Pierson, B.J., Eberli, G.P., Al-Mehsin, K.M., Al-Menhali, S., Warrlich, G., Droste, H.J., Maurer, F., Whitworth, J. and Drysdale, D. (2010) Seismic stratigraphy and depositional history of the Upper Shu'aiba (Late Aptian) in the UAE and Oman. In: Barremian - Aptian Stratigraphy and Hydrocarbon Habitat of the Eastern Arabian Plate (Eds F.S.P. van Buchem, M.I. Al-Husseini, F. Maurer and H.J. Droste), GeoArabia Spec. Publ. 4, Gulf PetroLink, Bahrain, 2, 411-444.

Pinet, P.R. and Popenoe, P. (1985) A scenario of MesozoicCenozoic ocean circulation over the Blake Plateau and its environs. GSA Bull., 5, 618-626.

Pinet, P.R., Popenoe, P. and Nelligan, D.F. (1981) Gulf stream: reconstruction of Cenozoic flow patterns over the Blake Plateau. Geology, 9, 266-270.

Pittet, B., Van Buchem, F.S.P., Hillgärtner, H., Razin, P., Grötsch, J. and Droste, H. (2002) Ecological succession, palaeoenvironmental change, and depositional sequences of Barremian-Aptian shallow-water carbonates in northern Oman. Sedimentology, 49, 555-581.

Posamentier, H.W., Jervey, M.T. and Vail, P.R. (1988) Eustatic controls on clastic deposition I - conceptual framework. In: Sea Level Changes - An Integrated Approach (Eds C.K. Wilgus, B.S. Hastings, C.G.St.C. Kendall, H.W. Posamentier, C.A. Ross and J.C. van Wagoner), SEPM Spec. Publ., 42, 109-124.

Price, G.D. (1999) The evidence and implications of polar ice during the Mesozoic. Earth Sci. Rev., 48, 183-210.

Pucéat, E., Lécuyer, C., Sheppard, S.M.F., Dromart, G., Reboulet, S. and Grandjean, P. (2003) Thermal evolution of Cretaceous Tethyan marine waters inferred from oxygen isotope composition of fish tooth enamels. Paleoceanography, 18, 7.1-7.12.

Querol, X., Salas, R., Pardo, G. and Ardèvol, L. (1992) Albian coal-bearing deposits of the Iberian Range in NE 
Spain. In: Controls on the Distribution and Quality of Cretaceous Coals (Eds P.J. McCabe and J.T. Parrish), Geol. Soc. Am. Spec. Pap., 267, 193-207.

Rameil, N., Immenhauser, A., Csoma, A.É. and Warrlich, G. (2012) Surfaces with a long history: the Aptian top Shu'aiba Formation unconformity, Sultanate of Oman. Sedimentology, 59, 212-248.

Raven, M.J., van Buchem, F.S.P., Larsen, P.-H., Surlyk, F., Steinhardt, H., Cross, D., Klem, N. and Emang, M. (2010) Late Aptian incised valleys and siliciclastic infill at the top of the Shu'aiba Formation (Block 5, offshore Qatar). In: Barremian - Aptian Stratigraphy and Hydrocarbon Habitat of the Eastern Arabian Plate (Eds F.S.P. van Buchem, M.I. Al-Husseini, F. Maurer and H.J. Droste), GeoArabia Spec. Publ. 4, Gulf PetroLink, Bahrain, 2, 469-502.

Röhl, U. and Ogg, J.G. (1998) Aptian-Albian eustatic sealevels. In: Reefs and Carbonate Platforms in the Pacific and Indian Oceans (Eds G.F. Camoin and P.J. Davies), IAS Spec. Publ., 25, 95-136.

Rosales, I. (1999) Controls on carbonate-platform evolution on active fault blocks: the Lower Cretaceous Castro Urdiales platform (Aptian-Albian, northern Spain). J. Sed. Res., 69, 447-465.

Ruberti, D., Bravi, S., Carannante, G., Vigorito, M. and Simone, L. (2013) Decline and recovery of the Aptian carbonate factory in the southern Apennine carbonate shelves (southern Italy): climatic/oceanographic vs. local tectonic controls. Cretaceous Res., 39, 112-132.

Rückheim, S., Bornemann, A. and Mutterlose, J. (2006) Planktic foraminifera from the mid-Cretaceous (BarremianEarly Albian) of the North Sea Basin: palaeoecological and palaeoceanographic implications. Mar. Micropaleontol., 58, 83-102.

Sahagian, D., Pinous, O., Olferiev, A. and Zakharov, V. (1996) Eustatic curve for the Middle Jurassic-Cretaceous based on Russian Platform and Siberian stratigraphy: zonal resolution. AAPG Bull., 80, 1433-1458.

Salas, R. (1987) El Malm i el Cretaci inferior entre el Massís de Garraf i la Serra d'Espadà. Anàlisi de Conca. PhD thesis. Universitat de Barcelona, p. 345.

Salas, R. and Casas, A. (1993) Mesozoic extensional tectonics, stratigraphy, and crustal evolution during the Alpine cycle of the eastern Iberian basin. Tectonophysics, 228, 33-55.

Salas, R. and Guimerà, J. (1996) Rasgos estructurales principales de la cuenca cretácica inferior del Maestrazgo (Cordillera Ibérica oriental). Geogaceta, 20, 1704-1706.

Salas, R., Guimerà, J., Mas, R., Martín-Closas, C., Meléndez, A. and Alonso, A. (2001) Evolution of the Mesozoic Central Iberian Rift System and its Cainozoic inversion (Iberian Chain). In: Peri-Tethys Memoir 6: Peri-Tethyan Rift/Wrench Basins and Passive Margins (Eds P.A. Ziegler, W. Cavazza, A.H.F. Roberston and S. Crasquin-Soleau), 186, pp. 145-186. Mémoires du Muséum National d'Histoire Naturelle, Paris.

Schroeder, R., van Buchem, F.S.P., Cherchi, A., Baghbani, D., Vincent, B., Immenhauser, A. and Granier, B. (2010) Revised orbitolinid biostratigraphic zonation for the Barremian - Aptian of the eastern Arabian Plate and implications for regional stratigraphic correlations. In: Barremian - Aptian Stratigraphy and Hydrocarbon Habitat of the Eastern Arabian Plate (Eds F.S.P. van Buchem, M.I. Al-Husseini, F. Maurer and H.J. Droste), GeoArabia Spec. Publ. 4, Gulf PetroLink, Bahrain, 1, 49-96.
Skelton, P.W. (2003a) The Cretaceous World. Cambridge University Press, ???, p. 360.

Skelton, P.W. (2003b) Rudist evolution and extinction - a north African perspective. In: North African Cretaceous Carbonate Platform Systems (Eds E. Gili, M. Negra and P.W. Skelton), NATO Science Series IV, Earth Environ. Sci., 28, 215-227.

Skelton, P.W. and Gili, E. (2012) Rudists and carbonate platforms in the Aptian: a case study on biotic interactions with ocean chemistry and climate. Sedimentology, 59, 81-117.

Skelton, P.W., Gili, E., Bover-Arnal, T., Salas, R. and Moreno-Bedmar, J.A. (2010) A new species of Polyconites from the uppermost Lower Aptian of Iberia and the early evolution of polyconitid rudists. Turk. J. Earth Sci., 19, $557-572$.

Solé de Porta, N. and Salas, R. (1994) Conjuntos microflorísticos del Cretácico inferior de la Cuenca del Maestrazgo. Cordillera Ibérica Oriental (NE de España). Cuad. Geol. Ibérica, 18, 355-368.

Stein, M., Arnaud-Vanneau, A., Adatte, T., Fleitmann, D., Spangenberg, J.E. and Föllmi, K.B. (2012) Palaeoenvironmental and palaeoecological change on the northern Tethyan carbonate platform during the Late Barremian to earliest Aptian. Sedimentology, 59, 939-963.

Steuber, T., Rauch, M., Masse, J.-P., Graaf, J. and Malkoc, M. (2005) Low-latitude seasonality of Cretaceous temperatures in warm and cold episodes. Nature, 437, 1341-1344.

Stoll, H.M. and Schrag, D.P. (1996) Evidence for glacial control of rapid sea level changes in the Early Cretaceous. Science, 272, 1771-1774.

Strasser, A., Pittet, B., Hillgärtner, H. and Pasquier, J.-B. (1999) Depositional sequences in shallow carbonatedominated sedimentary systems: concepts for a highresolution analysis. Sed. Geol., 128, 201-221.

Vail, P.R., Mitchum ., R.M., Jr, Todd, J.R.G., Widmier, J.M., Thompson, S., III, Sangree, J.B., Bubb, J.N. and Hatlelid, W.G. (1977) Seismic stratigraphy and global changes of sea level. In: Seismic Stratigraphy: Applications to Hydrocarbon Exploration (Ed. C.E. Payton), Am. Assoc. Petrol. Geol. Mem., 26, 49-212.

Vail, P.R., Audemard, F., Bowman, S.A., Eisner, P.N. and Perez-Cruz, C. (1991) The stratigraphic signatures of tectonics, eustasy and sedimentology - an overview. In: Cycles and Events in Stratigraphy (Eds G. Einsele, W. Ricken and A. Seilacher), pp. 617-659. Springer, Berlin.

Van Wagoner, J.C., Posamentier, H.W., Mitchum, R.M., Vail, P.R., Sarg, J.F., Loutit, T.S. and Hardenbol, J. (1988) An overview of the fundamentals of sequence stratigraphy and key definitions. In: Sea Level Changes: An Integrated Approach (Eds C.K. Wilgus, B.S. Hastings, C.G.St.C. Kendall, H.W. Posamentier, C.A. Ross and J.C. van Wagoner), SEPM Spec. Publ., 42, 39-45.

Vennin, E. and Aurell, M. (2001) Stratigraphie séquentielle de l'Aptien du sous-bassin de Galvé (Province de Teruel, NE de l'Espagne). Bull. Soc. Géol. Fr., 172, 397-410.

Vilas, L., Masse, J.P. and Arias, C. (1995) Orbitolina episodes in carbonate platform evolution: the early Aptian model from SE Spain. Palaeogeogr. Palaeoclimatol. Palaeoecol., 119, 35-45.

Weissert, H. and Lini, A. (1991) Ice age interludes during the time of Cretaceous greenhouse climate? In: Controversies in Modern Geology: Evolution of Geological Theories in Sedimentology, Earth History and Tectonics (Eds D.W. 
Müller, J.A. McKenzie and H. Weissert), pp. 173-191. Academic Press, London.

Wilmsen, M., Fürsich, F.T. and Majidifard, M.R. (2013) The Shah Kuh Formation, a latest Barremian - Early Aptian carbonate platform of Central Iran (Khur area, Yazd Block). Cretac. Res., 39, 183-194.

Wilson, P.A. and Norris, R.D. (2001) Warm tropical ocean surface and global anoxia during the mid-Cretaceous period. Nature, 412, 425-429.

Wissler, L., Funk, H. and Weissert, H. (2003) Response of Early Cretaceous carbonate platforms to chages in atmospheric carbon dioxide levels. Palaeogeogr. Palaeoclimatol. Palaeoecol., 200, 187-205.

Yilmaz, I.Ö. and Altiner, D. (2006) Cyclic palaeokarst surfaces in Aptian peritidal carbonate successions (Taurides, southwest Turkey): internal structure and response to mid-Aptian sea-level fall. Cretaceous Res., 27, 814-827.

Yose, L.A., Strohmenger, C.J., Al-Hosani, I., Bloch, G. and Al-Mehairi, Y. (2010) Sequence-stratigraphic evolution of an Aptian carbonate platform (Shu'aiba Formation), eastern Arabian Plate, onshore Abu Dhabi, United Arab Emirates. In: Barremian - Aptian Stratigraphy and
Hydrocarbon Habitat of the Eastern Arabian Plate (Eds F.S.P. van Buchem, M.I. Al-Husseini, F. Maurer and H.J. Droste), GeoArabia Spec. Publ. 4, Gulf PetroLink, Bahrain, 2, 309-340.

Zaitlin, B.A., Dalrymple, R.W. and Boyd, R. (1994) The stratigraphic organisation of incised valley systems associated with relative sea- level change. In: Incised Valley Systems: Origin and Sedimentary Sequences (Eds R.W. Dalrymple, R.J. Boyd and B.A. Zaitlin), SEPM Spec. Publ., 51, 45-60.

Zaitlin, B.A., Warren, M.J., Potocki, D., Rosenthal, L. and Boyd, R. (2002) Depositional styles in a low accommodation foreland basin setting: an example from the Basal Quartz (Lower Cretaceous), southern Alberta. Bull. Can. Petrol. Geol., 50, 31-72.

Zorian, S.O. and Ruban, D.A. (2012) Hauterivian-Aptian (Early Cretaceous) transgression-regression cycles on the eastern Russian Platform and their inter-regional correlation. GeoActa, 11, 41-50.

Manuscript received 28 March 2013; revision accepted 10 January 2014 


\section{Author Query Form}

Journal: $\quad$ SED

Article: 12105

Dear Author,

During the copy-editing of your paper, the following queries arose. Please respond to these by marking up your proofs with the necessary changes/additions. Please write your answers on the query sheet if there is insufficient space on the page proofs. Please write clearly and follow the conventions shown on the attached corrections sheet. If returning the proof by fax do not write too close to the paper's edge. Please remember that illegible mark-ups may delay publication.

Many thanks for your assistance.

\begin{tabular}{|c|c|c|}
\hline Query reference & Query & Remarks \\
\hline 1 & $\begin{array}{l}\text { AUTHOR: Garcia et al. } 2013 \text { has been changed to Garcia et al., } \\
2014 \text { so that this citation matches the Reference List. Please confirm } \\
\text { that this is correct. }\end{array}$ & \\
\hline 2 & $\begin{array}{l}\text { AUTHOR: This sentence has been modified as per the stylesheet } \\
\text { requirement. Please check whether it is appropriate and approve. }\end{array}$ & \\
\hline 3 & $\begin{array}{l}\text { AUTHOR: Do you mean, “...that the growth and melting of large } \\
\text { continental ice-sheets were the main process controlling...”? Please } \\
\text { check. }\end{array}$ & \\
\hline 4 & $\begin{array}{l}\text { AUTHOR: Please provide the publisher location for reference } \\
\text { Canérot et al. (1982). }\end{array}$ & \\
\hline 5 & $\begin{array}{l}\text { AUTHOR: Please provide the publisher location for reference } \\
\text { Church and Gregory (2001). }\end{array}$ & \\
\hline 6 & $\begin{array}{l}\text { AUTHOR: Please provide the publisher location for reference Cloet- } \\
\text { ingh (1991). }\end{array}$ & \\
\hline 7 & $\begin{array}{l}\text { AUTHOR: Please provide the publisher location for reference } \\
\text { Frakes and Francis (1990). }\end{array}$ & \\
\hline 8 & $\begin{array}{l}\text { AUTHOR: Please provide the volume number and page range for } \\
\text { reference Garcia et al. (2014). }\end{array}$ & \\
\hline 9 & $\begin{array}{l}\text { AUTHOR: Please provide the page range for reference Hardenbol et } \\
\text { al. (1998). }\end{array}$ & \\
\hline 10 & AUTHOR: Please check the journal title for correctness. & \\
\hline 11 & $\begin{array}{l}\text { AUTHOR: Please provide the publisher location for reference Skel- } \\
\text { ton (2003a). }\end{array}$ & \\
\hline 12 & AUTHOR: Please check the journal title for correctness. & \\
\hline
\end{tabular}


Once you have Acrobat Reader open on your computer, click on the Comment tab at the right of the toolbar:

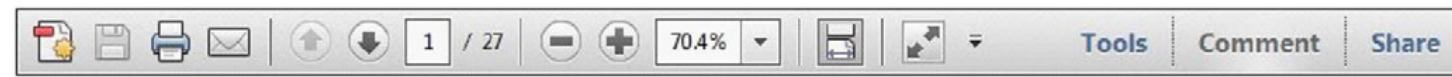

This will open up a panel down the right side of the document. The majority of tools you will use for annotating your proof will be in the Annotations section, pictured opposite. We've picked out some of these tools below:

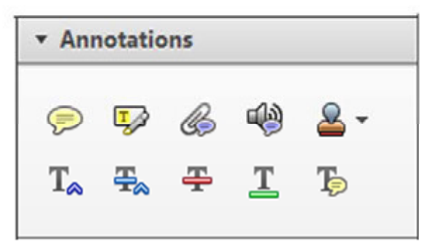

1. Replace (Ins) Tool - for replacing text.

\section{Ttrikes a line through text and opens up a text box where replacement text can be entered.}

\section{How to use it}

- Highlight a word or sentence

- Click on the Replace (Ins) icon in the Annotations section.

- Type the replacement text into the blue box that appears.

Idard framework for the analysis of $\mathrm{m}$ icy Nevertheless, it also led, to exog,

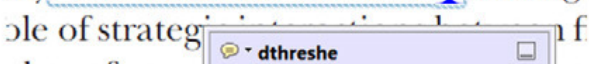
aber of comp 08/06/2011 15:58:17

: is that the $\mathrm { s } 1 \longdiv { \text { , which led } }$ of nain compo be

level, are exc nc important wow or cme oy wire M honeforth) ${ }^{1}$ we snen the hlacl t

3. Add note to text Tool - for highlighting a section to be changed to bold or italic.

T. Highlights text in yellow and opens up a text box where comments can be entered.

\section{How to use it}

- Highlight the relevant section of text.

- Click on the Add note to text icon in the Annotations section.

- Type instruction on what should be changed regarding the text into the yellow box that appears.

namic responses of mark ups ent with the VAR evidence

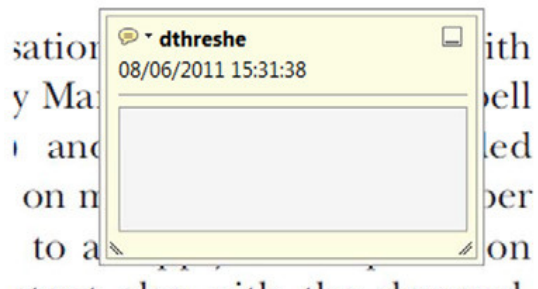

2. Strikethrough (Del) Tool - for deleting text.

Strikes a red line through text that is to be deleted.

\section{How to use it}

- Highlight a word or sentence.

- Click on the Strikethrough (Del) icon in the Annotations section.

there is no room for extra prohts au : ups are zero and the number of set) values are not determined by Blanchard and Kiyotaki (1987), sfect competition in general equilil ts of aggregate demand and supply lassical framework assuming mono] aan on avoranowe numbar of firme

\section{Add sticky note Tool - for making notes at specific points in the text.}

Marks a point in the proof where a comment needs to be highlighted.

\section{How to use it}

- Click on the Add sticky note icon in the Annotations section.

- Click at the point in the proof where the comment should be inserted.

- Type the comment into the yellow box that appears.

ldilu dilu suppiy silucks. Hivst ul

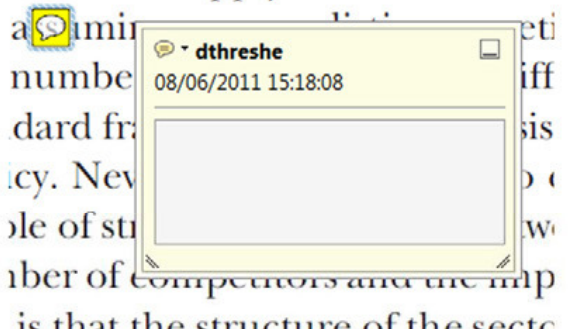


5. Attach File Tool - for inserting large amounts of text or replacement figures.

Inserts an icon linking to the attached file in the appropriate pace in the text.

How to use it

- Click on the Attach File icon in the Annotations section.

- Click on the proof to where you'd like the attached file to be linked.

- Select the file to be attached from your computer or network.

- Select the colour and type of icon that will appear in the proof. Click OK.

\section{E N D}

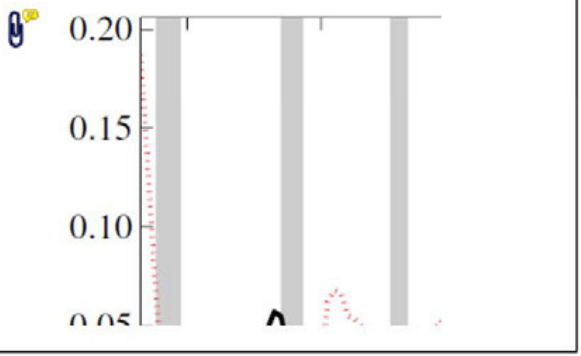

6. Drawing Markups Tools - for drawing shapes, lines and freeform annotations on proofs and commenting on these marks.

Allows shapes, lines and freeform annotations to be drawn on proofs and for comment to be made on these marks.

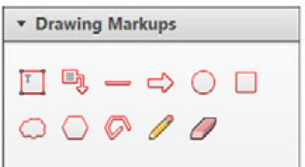

How to use it

- Click on one of the shapes in the Drawing Markups section.

- Click on the proof at the relevant point and draw the selected shape with the cursor.

- To add a comment to the drawn shape, move the cursor over the shape until an arrowhead appears.

- Double click on the shape and type any text in the red box that appears.

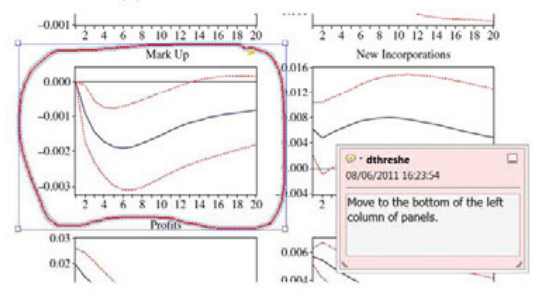

